\title{
Building Resilience to Chronic Landslide Hazard Through Citizen Science
}

\author{
Katarzyna Cieslik ${ }^{1 *}$, Puja Shakya ${ }^{2}$, Madhab Uprety $^{2}$, Art Dewulf $^{1}$, Caroline Russell ${ }^{3}$, \\ Julian Clark ${ }^{3}$, Megh Raj Dhital ${ }^{4}$ and Amrit Dhakal ${ }^{4}$
}

\begin{abstract}
1 Public Administration and Policy Group, School of Social Science, Wageningen University \& Research, Wageningen, Netherlands, ${ }^{2}$ Practical Action (Nepal), Kathmandu, Nepal, ${ }^{3}$ School of Geography, Earth and Environmental Sciences, University of Birmingham, Birmingham, United Kingdom, ${ }^{4}$ Department of Geology, Tribhuvan University, Kirtipur, Nepal
\end{abstract}

\section{OPEN ACCESS}

Edited by:

Jonathan D. Paul, Imperial College London,

United Kingdom

Reviewed by:

Emanuele Intrieri,

University of Florence, Italy

Davide Tiranti,

Agenzia Regionale per la Protezione Ambientale (ARPA), Italy

*Correspondence: Katarzyna Cieslik kc566@cam.ac.uk

Specialty section:

This article was submitted to Geohazards and Georisks, a section of the journal

Frontiers in Earth Science

Received: 22 January 2019

Accepted: 17 October 2019

Published: 07 November 2019

Citation:

Cieslik K, Shakya P, Uprety M,

Dewulf A, Russell C, Clark J, Dhital MR and Dhakal A (2019)

Building Resilience to Chronic Landslide Hazard Through Citizen Science. Front. Earth Sci. 7:278. doi: 10.3389/feart.2019.00278
Landslides disrupt livelihoods, cause loss of human lives and damages to property and infrastructure. In the case of Nepal, the destructive impact of landslides has been steadily increasing as a result of the rising occupation of marginal land and extreme weather events caused by climate change. In particular, the impacts of seasonal, shallow landslides have been underestimated due to underreporting, and lack appropriate policy response. Within this paper, we argue that citizen science - the practice of incorporating the general public in the process of knowledge co-production - may help address this issue by increasing the knowledge base of stakeholders at different levels. We present the preliminary results from an interdisciplinary scoping study of two landslide sites in Western Nepal, in Bajhang and Bajura, where the Landslide-EVO research project, including a citizen science component, is currently being implemented. The aim of the project is to innovate participatory environmental monitoring and to generate evidence to support resilience. Our exploratory qualitative investigation outlines the strategies currently employed by the local communities that continue living in the landslide affected areas. These include demographic shifts and patterns, land use changes and occupational diversification. We argue that these existing local adaptation and mitigation practices compound a wealth of experiential knowledge. Based on evidence from literature, as well as our first-hand experience of starting citizen science activities in the both landslide sites, we argue that citizen science has the potential to build on local knowledge base and strengthen the adaptive capacities of different level stakeholders. Our theoretical contribution is the proposed typology of citizen-science interventions. We distinguish between community science, participatory environmental monitoring and virtual citizen science, providing examples of how they can benefit stakeholders at different levels and/or different types of research. Finally, we examine the ways in which different types of citizen science could be applied in our case study sites, specifying the conditions under which they can attain maximum usefulness.

Keywords: citizen science, Nepal, local knowledge, participatory science, landslide, chronic hazard 
Interviewer: You said that there are houses here, at the peak of the landslide. What do the people who live here do during the monsoon season? Do they move to a safer place?

Informant: Nah. What can we do? Our houses are there so we cannot just leave everything and go to another place as we do not own land in other place! So even if we have to die, we will live and die in our own house; that is what we think.

/BARBELKA, Bitthadchir, Bajhang/

\section{INTRODUCTION}

In geological terms, "landslide" describes a broad variety of processes that result in the slope-forming materials falling, toppling, sliding, spreading, or flowing down the mountain side (Cruden and Varnes, 1996; Kirschbaum et al., 2010). While big and acute landslides tend to garner public attention due to their immediate destructive nature, smaller seasonal landslides also have lasting detrimental implications for the inhabitants of the risk zones (Sudmeier-Rieux et al., 2012; Sidle et al., 2017). Apart from direct risk to people's lives and health, seasonal landslides result in gradual land and property loss that can seriously threaten the livelihoods and food security of the mountain communities (Tobin et al., 2011; Arouri et al., 2015).

At the same time, the recurrent and unremitting nature of chronically occurring hazards presents an unparalleled opportunity for community-level experimentation and learning (Hermelin and Bedoya, 2008; Lacasse and Nadim, 2009). Contrary to acute landslides which tend to result in largescale resettlement schemes (Vlaeminck et al., 2016), populations exposed to chronic landslide hazard often continue living in the risk zones and applying a range of mitigation and adaptation strategies (Glade and Crozier, 2005; Gentle and Maraseni, 2012; Sudmeier-Rieux et al., 2012; Vaciago, 2013). For this reason, we believe that certain forms of citizen science - the process of knowledge co-generation by societal actors and scientists has the potential to leverage these local capacities, improving community resilience.

This paper shares learning from a citizen-science based project, Landslide-EVO, currently underway in two landslide sites in Western Nepal, in Bajhang and Bajura districts. The aim of the project is to innovate participatory environmental monitoring and to generate evidence to support resilient livelihoods. Basing our analysis on individual and group interviews conducted in the settlements on the landslideprone slopes, we outline the strategies employed by the local communities as means of adapting to living with a chronic landslide hazard. These include demographic shifts and patterns, land use changes and alternative occupational choices as well as experiential, generational knowledge of various mitigation measures. We argue that even though these practices enabled the communities to continue living in the hazard-prone area, presently they have little potential to improve livelihoods in the long run.

In the second part of the paper we propose a set of guidelines for citizen science - based approaches for chronic hazard monitoring. Studies have demonstrated that citizen scientists can both provide good quality data for scientific modeling and forecasting and prompt community sensitization and engagement (Bonney et al., 2009; Buytaert et al., 2014; Stone et al., 2014; Jacobs et al., 2019). At the same time, the very concept of citizen science emerged and gained popularity in Western Europe and North America (Haklay M., 2013). When applied to development contexts - such as rural Nepal its contribution to the existing participatory approaches is unclear (Gaventa and Barrett, 2010). For this reason, in our theoretical model, we distinguish between participatory science (community science), participatory environmental monitoring, and virtual citizen science. We enlist the main attributes of each of these approaches, comparing and contrasting their utility for different research contexts. Finally, we describe the first attempt of introducing citizen-science activities in our case study sites, specifying the conditions under which they can attain maximum usefulness.

The contribution of the paper is twofold. First, we identify, describe and categorize the locally evolved strategies that allow the local communities to continue living on the landslideprone slopes despite the continuously shrinking livelihood options. Second, we discuss the ways in which citizen science approaches may help navigate the daily uncertainties that the local stakeholders face, paving the way for more social impact in science.

\section{CHRONIC LANDSLIDE HAZARD - POLICY CHALLENGES AND THE PROMISE OF CITIZEN SCIENCE}

\section{The Underestimated Hazard: The Destructive Significance of Seasonal Landslides}

In the slope failures classification, deep-seated landslides are those in which the bulk of the slide surface lies below the roots of trees (Barik et al., 2017). The occurrence and velocity of these slides are often linked with the changes in the geologic and hydrologic processes in the area, such as earthquakes and fluctuating ground water levels (Van Den Eeckhaut et al., 2009). On the contrary, shallow landslides are characterized by land mass flows occurring within the forest rooting zone (Cohen and Schwarz, 2017). Shallow landslides are most often seasonal: they are initiated by intense rainfall during monsoon, when the saturation of the ground loosens the soil structure. They tend to be accompanied by a mudflow and/or a debris flow (Guzzetti et al., 2008).

Interestingly, deep-seated landslides have a minimal effect on mountain communities' livelihoods and may stay unheeded for extended periods of time, up until the ecosystem's "tipping point" has been reached and a major catastrophic event occurs (Hilley et al., 2004). In majority of cases, due to the collapse of ecosystem process functions, recovery is not possible (Sidle et al., 2006). Deep-seated landslides are thus considered to be "acute" events (Broothaerts et al., 2012). 
In contrast, in the case of shallow landslides, human settlements are immediately impacted: though smaller in scale and range, these slides cause immediate damage to households and livelihoods: they tear down terraced farmlands, result in livestock loses, knock down houses and disrupt local infrastructure (irrigation, drinking water piping, roads and passageways). In the case of Nepal, these impacts have been gradually increasing over the past years, due to the rising occupation of marginal land and changing weather patterns related to climate change (Petley et al., 2007). The seasonal, unrelenting character of shallow landslides gradually exhausts the adaptive capacity of human settlements: the ever-decreasing amount of agricultural land imposes major structural changes in the livelihood strategies, deeply affecting the social institutions of the mountain communities (Gerrard and Gardner, 2002; Sudmeier-Rieux et al., 2012; Pisano et al., 2017).

From the point of view of disaster management, the distinction between deep-seated landslides resulting in oneoff, large-scale events and shallow, seasonal landslides, has important implications for policy and practice. While very little can be done to stop the deep-seated landslides, the advance of shallow landslides can, in some cases, be mitigated with the right combination of land engineering, draining and reinforcement and large-scale afforestation schemes (Stokes et al., 2014). In particular, changes in land use hold considerable promise to help local communities attenuate the impact of landslides (Glade, 2003; Che et al., 2011; Petrone and Perti, 2013; Persichillo et al., 2017).

While a number of these studies identified the human factors that result in slope instability, little has been done to translate these insights into policy making. This is because of three major problems. First, the seasonally occurring, shallow landslides remain largely underreported (Kervyn et al., 2015; Kirschbaum et al., 2015). The global and national landslide reporting databases suffer from regional bias, and marginal areas (rural provinces, grassland and forest covered localities) remain underrepresented for decades (Sudmeier-Rieux et al., 2013). Guzzetti et al., 2012 estimate that "landslide maps cover less than $1 \%$ of the slopes in the landmasses, and systematic information on the type, abundance, and distribution of landslides is lacking" (2012: 42). Secondly, predominantly non-fatal, shallow landslides are too frequent and commonplace to attract the attention of the local officials and trigger a timely policy response (Guzzetti, 2000). Finally, the extent to which mitigation interventions can be effective varies across contexts and timescales. For example, while afforestation might help lessen the landslide impacts in one area at a given point in time, it might no longer work a couple of years later due to the change in monsoon intensity (Stokes et al., 2014). Similarly, if preventing overgrazing seems to have an effect in one locality, it might not work in others (depending on erosion rates, soil structure, precipitation, etc.). A number of misconceptions and myths exist regarding the extent to which landslides can be managed and the appropriate course of action. As a result, mountain communities are often left to their own devices to adapt to their harsh environments, mitigate the hazard impacts and persevere in their livelihood choices.

\section{Local Knowledge Integration and the Promise of Citizen Science - Evidence From Literature}

Interestingly, studies have shown that the traditional, locally evolved practices can effectively improve disaster preparedness and response (Dekens, 2007; Gardner and Dekens, 2007; Hiwasaki et al., 2014). We define local knowledge as unique, experiential knowledge developed over an extended period of time and held by a group of people in a specific location (Roncoli et al., 2002). Particularly in the case of water-induced hazards like floods and landslides, local knowledge offers invaluable insights about the disaster dynamics and frugal preventive measures (Alcántara-Ayala, 2004; Maes et al., 2019; see also Shaw et al., 2008). Current studies in disaster risk reduction bring evidence that it is in fact the over-reliance on top-down engineering structures and expert solutions that has an adverse effect on community resilience, creating dependencies and incapacitating local-level stakeholders (Wisner, 2006; Munroe et al., 2013).

Studies have shown that local knowledge systems are naturally geared toward coping with and adapting to changing environments (Turner and Clifton, 2009). At the same time, traditional knowledge systems often fail in confrontation with the fast-paced change induced by the Anthropocene (Naess, 2013). Recently, a growing body of research has been documenting cases where the integration of local and expert (scientific) knowledge(s) substantially increased the resilience of the hazard-prone communities (Mercer et al., 2010; Walshe and Nunn, 2012). For this reason, citizen science - a joint co-production of knowledge by the scientists and the concerned populations - has been growing in popularity in both the academe and the development sector (Bonney et al., 2009, 2014; McKinley et al., 2017).

Importantly, including local stakeholders in the processes of knowledge production has a long tradition in development studies, dating back to the groundbreaking work of Robert Chambers and Paul Freire. Credited with strengthening decisionmaking and having an empowering effect on populations, the tradition of participatory research has deeply impacted the way development is conceptualized and managed (Brosius et al., 1998; Campbell and Vainio-Mattila, 2003). Citizen science builds on this tradition but, due to the enabling role of technology (mainly, information and communication technology, ICT4D), allows to bring both participatory monitoring and scientific modeling to scale (Bonney et al., 2009; Haklay M., 2013; Jalbert and Kinchy, 2015).

Just like seasonally occurring shallow landslides, citizen science - based projects are cyclic in nature: annually/seasonally repeated, continuously revising the relevance of the outputs achieved and the usability of the information generated (Leeuwis et al., 2018). As such, citizen science projects go beyond the planned acquisition and processing of data, focusing instead on incremental learning, flexibility and adaptation (Silvertown, 2009). This learning occurs at different scales or levels of the system, including the scientists themselves, but also the 
citizens, knowledge communities, organizations and institutions. By allowing the researchers to better understand the diversity of epistemic viewpoints held by heterogonous stakeholders, citizen science has the potential to boost the existing adaptation and mitigation practices, contributing to long-term resilience building. Table $\mathbf{1}$ provides an overview of citizen science uses in disaster contexts, ranging from oil spills and forest fires to floods, landslides, and earthquakes.

\section{RESILIENCE TO CHRONIC LANDSLIDES}

In recent years, resilience has become the key term in interdisciplinary frameworks used to describe and explain how humans cope with environmental shocks and stressors (Folke et al., 2002; Walker et al., 2004). By directing the attention from vulnerability (deficiencies and incapacities) to the dynamic interaction between ecosystems and their human inhabitants, resilience has come to denote the capacity of systems to absorb change (Folke et al., 2010).

Within disaster studies, the application of the "resilience framework" has been steadily growing over the past decade, slowly becoming the normative standard for researchers and practitioners working with natural hazards. At the same time, Barrios (2016) observes that the definitions of resilience make a number of assumptions about the nature of communities and their preferences pertaining to coping with the disaster's impact. The supposed "bouncing back" to the pre-disaster state implies that the hazardous event was a singular, surprising occurrence and that the pre-disaster state was, in fact, acceptable and desired (Schuller, 2012). Looking at the socio-economic conditions of a number of disaster-prone communities, he argues that the state of extreme poverty, deprivation, vulnerability, dependency and general underdevelopment should not be considered the desired outcome of a "resilient" post-disaster recovery.

This translation of resilience into "bouncing back" has been questioned in terms of which state of affairs is desirable to bounce back to. When the focus is on bouncing back, resilience becomes a conservative concept (Olsson et al., 2015) that does not challenge the status quo, which might be socially unjust, environmentally unsustainable, or overly risky (Béné et al., 2018). Particularly in the field of disaster resilience, criticism has been voiced about the "unquestioned acceptance of recovery and rebuilding policies and activities that re-inscribed pre-existing power structures and gender inequities" (Cox and Perry, 2011: 408). One response to this critique has been to emphasize the possibility and desirability of "bouncing forward," implying a view of resilience in terms of "building adaptive capacity for positive change" (de Milliano et al., 2015: 21). Others have gone further by coupling resilience with transformation (Folke et al., 2010; Pelling and Manuel-Navarrete, 2011; Mao et al., 2017). From an evolutionary resilience view (White and O'Hare, 2014), where there is no assumption of a stable state, "it is not about bouncing back to where we were, but about the capacity for adaptation and, crucially, for transformation. it is about the capacity to break away from undesirable 'normal'." (Davoudi, 2018: 4).

In areas where both development and disaster risk reduction are key concerns, the distinction between humanitarian resilience and development resilience is valuable (Barrett and Constas, 2014). Here, humanitarian resilience in the sense of dealing with disasters is considered necessary but not sufficient in the absence of development resilience. Development resilience is

TABLE 1 | Example of citizen science use in disaster contexts.

\begin{tabular}{|c|c|c|}
\hline Research article & Nature of the hazard and locality & Type of citizen science applied \\
\hline Meier et al., 2012 & Kenya, Haiti, Japan, Libya, and Somalia & Crowdsourced data: CrisisMapping, Ushahidi \\
\hline Cochran et al., 2009; Liang et al., 2017 & Earthquakes in Taiwan & $\begin{array}{l}\text { Crowdsourced data: Quake-Catcher Network (QCN): seismic network } \\
\text { that implements distributed/volunteer computing with the potential to } \\
\text { provide critical earthquake information by filling in the gaps between } \\
\text { traditional seismic stations }\end{array}$ \\
\hline Goodchild and Glennon, 2010 & Wildfires in Santa Barbara & $\begin{array}{l}\text { Crowdsourced data: risk mapping, post-disaster need mapping using } \\
\text { social media }\end{array}$ \\
\hline Hassanzadeh and Nedovic-Budic, 2014 & Earthquake in Bam City (Iran) & $\begin{array}{l}\text { Crowdsourced data paired with remote sensing and predictive } \\
\text { modeling }\end{array}$ \\
\hline McCormick, 2012 & Deepwater Horizon oil spill in the Gulf Coast & $\begin{array}{l}\text { Crowdsourced data: geo-referenced observations and photographs; } \\
\text { organized via grass-roots }\end{array}$ \\
\hline Chu and Chen, 2018 & Landslide hot spots and debris flows & Crowdsourced data of hazard photographs \\
\hline Degrossi et al., 2014 & Flood risk management in Brazil & Crowdsourced data: Flood Citizen Observatory \\
\hline Marchezini et al., 2017 & $\begin{array}{l}\text { Prototyping an early warning system for floods } \\
\text { in Brazil }\end{array}$ & Workshops and participatory mapping with high school students \\
\hline Le Coz et al., 2016 & $\begin{array}{l}\text { Flood risk mapping and visualization in } \\
\text { Argentina, France and New Zealand }\end{array}$ & $\begin{array}{l}\text { Online repository of videos and photos of flash floods: Flood Chasers, } \\
\text { FloodScale RiskScape }\end{array}$ \\
\hline Zook et al., 2010 & Post disaster relief: Haiti earthquake & $\begin{array}{l}\text { Crowdsourced data: CrisisCamp Haiti, OpenStreetMap, Ushahidi, and } \\
\text { GeoCommons }\end{array}$ \\
\hline De Longueville et al., 2010 & Reporting flood events in the United Kingdom & Crowdsourced data: geo-referenced Flickr images \\
\hline Wald et al., 2011 & $\begin{array}{l}\text { Recording Earth shaking intensities for } \\
\text { earthquakes in the United States and around } \\
\text { the globe }\end{array}$ & $\begin{array}{l}\text { Macro-seismic United States Geological Survey's "Did You Feel It" } \\
\text { (DYFI): system has automatically collected shaking and damage reports } \\
\text { from Internet users immediately following earthquakes }\end{array}$ \\
\hline
\end{tabular}


then defined as "the capacity over time of a person, household or other aggregate unit to avoid poverty in the face of various stressors and in the wake of myriad shocks. If and only if that capacity is and remains high over time, then the unit is resilient" (Barrett and Constas, 2014: 14626). This is in line with Barrios's understanding of resilience as the capacity of a system to not just carry on, but also improvise, evolve and transform in response to the overwhelming challenges (Barrios, 2014, 2016).

In the case study presented below, we first analyze the resilience potential of the strategies currently applied by the communities exposed to chronic landslide hazard. Then, we present an overview of citizen-science based activities initiated by the Landslide-EVO project that may, somehow, improve the overall wellbeing of the concerned stakeholders rather than simply allowing them to persist in a given locality.

\section{METHODOLOGY}

Our investigation began with an in-depth analysis of existing secondary sources: these included research papers about landslide susceptibility of the study areas as well as demographic data available from the Nepalese Bureau of Statistics. We also consulted the geological reports to learn about the geomorphology of the sites as well as the general characteristics of acute and chronic landslides to learn about the implications they might have for local livelihoods.

We decided on a qualitative exploratory research approach (Miles and Huberman, 1994). This is because our aim was to get insights into how local inhabitants and stakeholder experience and respond to landslide hazard in their environment, and to learn into the potential of citizen science approaches in this context. Qualitative research methods such as participatory observation and semi-structured interviews allow researchers to capture respondents' views and behaviors while avoiding predetermined categories and possibly biased preconceptions on what is relevant and not to landslide resilience in this particular context. As opposed to structured surveys, qualitative interviewing allows the informants to choose the most relevant content, as well as the mode (flow) in which it is presented.

The field research was conducted in three stages: in November 2017, and then in March and July 2018. As the first stage of the data collection we conducted semi-structured group interviews in 14 settlements in the two study areas (Table 2). We first applied convenience sampling design (interviewing large groups in the center of the settlements, Robinson, 2014), followed by snowball sampling (talking to selected informants, e.g., household heads of the most affected families, Heckathorn, 2011), and finally deliberate sampling (interviewing the local government officials: mayors, deputies and the representatives of the Forestry and Water councils). Non-probability sampling (selecting samples based on the researcher's subjective judgment rather than randomly) is often used for qualitative exploratory studies that aim to discover trends, patterns and mechanisms and relationships between them, rather than generalize. The total of five individual interviews and eleven group interviews were conducted. The results were complemented by observation materials (notes and transcripts) and notes from two group discussion sessions.

We started off with semi-structured interviews, focusing on the following thematic areas: livelihood strategies, perceptions of landslides and their underlying causes, landslide-related problems and ways to amend them (if any). The interviews varied between 20 and $120 \mathrm{~min}$. All of the materials were transcribed and translated. Next, a two-stage analysis was employed: contentfocused, looking for emergent themes, and structural, focused on the coding categories of adaptation, mitigation and resilience) (Riessman, 2008).

\section{THE CASE STUDY: RESEARCH SITES: SUNKUDA (BAJHANG) AND BAJEDI (BAJURA)}

The two research sites chosen for the purpose of this study were Sunkuda (Bajhang) and Bajedi (Bajura). Both sites are located in the West part of Nepal, comprising two catchments in the Karnali basin in the Lesser Himalayas (Figures 1, 2).

In each of the research locations we can observe both the deep-seated and shallow slides. The last major landslide event in Sunkuda took place almost 50 years ago and in Bajedi 6 years ago. At the same time, both locations are continually experiencing seasonal shallow slides: in the case of Sunkuda it is mostly soil slides while in Bajedi it is rockslides. Research shows that the shallow landslides are not only the most common but also they exert the greatest impact on rural livelihoods in the Middle Hills Region (Sudmeier-Rieux et al., 2012). These impacts are expected to deepen considerably as a result of climate change (Petley et al., 2007).

\section{Geological Characteristics}

The district of Bajhang is characterized by extremely rugged topography with altitudes ranging from 915 to $7036 \mathrm{~m}$. The study area is located in the Lesser Himalayan Sequence, and comprises sedimentary and low-grade metamorphic rocks. The whole area of Bajhang is geologically fragile, prone to erosion and subject to rapid deterioration. Climatically, the Bajhang District falls under the alpine and temperate regions, with an annual average rainfall of $2200 \mathrm{~mm}$ and mean monthly temperatures of $5^{\circ} \mathrm{C}(\mathrm{min})$ and $40^{\circ} \mathrm{C}$ ( $\left.\max \right)$. According to the Relief Need Assessment report of District Administration Office, the district suffers from a high landslide risk. Other major hazards are heavy snowfall, flood, drought and fire.

The landslide of Sunkuda lies at the boundary of a thrust sheet of quartzites and schists resting over slates and dolomites (Figure 3). The slide occupies the south limb of a syncline, the axial trace of which passes through the stream valley (Dhital, 2015). It is essentially a single large soil slide (about $1 \mathrm{~km}$ long and $250 \mathrm{~m}$ wide) with a surface area of approximately $3.6 \mathrm{~km}^{2}$. The landslip is currently affecting a road and paddy grounds. It is about $25 \mathrm{~m}$ deep, translational debris slide. A stream is continuously eroding the toe of the slide and contributing to the instability. The slide seems to also exacerbated by road construction, since it interrupted the natural water course. 
TABLE 2 | Respondents: individual and group interviews.

\begin{tabular}{|c|c|}
\hline Data sources/Informants & Village/Municipality \\
\hline Group interview: ward heads/ teachers/political leaders/elders of the village/6-8 & BAJEDI, Budiganga, Bajura \\
\hline Individual interview: Village leader/ community members/8-12 & GUMLA, Chhededaha, Bajura \\
\hline Group interview: community members /random/6-10 & GUIBAN, Chhededaha, Bajura \\
\hline Group interview: community members/ a number of women present and participating/7-9 & THALAMEL TOLE, Budiganga, Bajura \\
\hline Group interview: community members /majority landless/10-50 & DALIT TOLE, Budiganga, Bajura \\
\hline Group interview: community members/7-9 & BASALI KOT, Budiganga, Bajura \\
\hline Individual interview: forestry office, district forest officer (DFO) & MARTADI, Bajura \\
\hline Individual interview: soil conservation office & MARTADI, Bajura \\
\hline Group interview: community members /a number of women present and participating/9-13 & DENSAYEL, Budiganga, Bajura \\
\hline Group interview: community members, school children, women and elderly also present/3-8 & NIMANI, Budiganga, Bajura \\
\hline Individual interview: key informant interview: retired teacher & THUMA, Budiganga, Bajura \\
\hline Group interview: ommunity members, mayor, teachers, social mobiliser/6-8 & SUNKUDA, Bitthadchir, Bajhang \\
\hline Group interview community members, including neighbouring households/12-14 & ADHIKARI TOLE/DALIT TOLE, KADAGAUN, Bitthadchir, Bajhang \\
\hline Individual (key informant) interview: head of household, lost his house twice & DHOKLA, Bitthadchir, Bajhang \\
\hline Group interview: ccommunity members/ women present/3-5 & BARBELKA, Bitthadchir, Bajhang \\
\hline Group interview: community members & KAPHELGAIRA, Bitthadchir, Bajhang \\
\hline Individual interview: district soil conservation officer & CHAINPUR, BHAJANG \\
\hline Individual interview: district forestry officer & CHAINPUR, BHAJANG \\
\hline
\end{tabular}

The district of Bajurais divided into three distinct regions from north to south: the Greater Himalayan Region, the Higher Mountain and the Mid Mountains. Geologically, the Bajedi Landslide of Bajura lies in the Lesser Himalayan Sequence of white quartzites, gray-green schists, gray dolomites and black slates. There are also a few bands of blue-green amphibolite and gray-green garnet schist. A sharp south-dipping active fault lies to the north of the landslide area. The quartzites, schists, and amphibolites of Proterozoic age compose the hanging wall of the thrust, whereas red-purple shales and gray-green sandstones of Miocene age constitute its footwall (Figure 4). Bajura has a cooler, temperate climate with annual rainfall of about $18,000 \mathrm{~mm}$ and temperature varying from 0 to $40^{\circ} \mathrm{C}$. The Bajedi landslide, which was chosen as our research site, is a large, deep-seated rockslide. It has been active for more than 30 years. The rockslide is approximately $3 \mathrm{~km}$ long, more than $500 \mathrm{~m}$ wide, more than $50 \mathrm{~m}$ deep, and covers about $2 \mathrm{~km}^{2}$.

The Bajedi slide of Bajura a number of smaller (less than ten meters) slides are also present within the watershed. The main failure mechanism is related to rock weathering and disintegration. Since the rock is much fractured, during the rainy season, water infiltrates into the ground and percolates to deeper levels (over $50 \mathrm{~m}$ deep). It then forms a continuous column that exerts pore pressure, leading to failure. The most active part of the slide is in the upper slopes, where it is propagating rapidly towards the ridge. The slide has formed multiple scarps and slices, especially in the upper and middle sections. The failed mass moves through gullies and streams into the main channel and generates debris flows in the downstream areas. In the past, this area used to be cultivated. It is highly probable that the combination of irrigation and heavy monsoon precipitation triggered the slope failure.

As mentioned before, both districts are subject to a wide range of natural hazards, in particular, landslides and flooding (including cascading effects). In both study sites, a syncline fold is present in the district and axial trace of syncline fold passes through the stream valley.

\section{Socio-Economic Characteristics}

Bajhang's total population comprises of about $66.54 \%$ Chhetri, $16 \%$ Dalits, $10.20 \%$ Brahmin, $7.33 \%$ Kamis, followed by others, in terms of caste and ethnicity. Caste-based discrimination is still common in many communities in Bajhang. Dalits are the most discriminated caste and are also particularly vulnerable to hazards. Most of the Dalits are confined to traditional professions such as blacksmith work, tailoring, goldsmith and copper work, as well as hired hands. Agriculture, cottage industries and trading are the main economic activities of the district. The major crops grown in the area are rice, wheat, maize, barley, millet, and buckwheat. Overall, the district is considered food-insecure, which can be attributed to both geographic (remote, drought and flood prone) and economic (lack of irrigation facilities, market access and infrastructure, i.e., transportation) factors. About 50\% of the total population of Bajhang lives under the poverty line.

Similarly to Bajhang, Bajura has a multi ethnic composition with Chhetri, Kami, Thakuri, Brahman, Magar, Damai, Sarki, Newar, Sherpa, Rai kirati and Sanyashi (Giri and Puri). The common language is Nepali (96\%) followed by Bhote Sherpa $(0.46 \%)$ and Tamang $(0.42 \%)$. Agriculture (including livestock/poultry) is the main occupation and source of income of the district, with some additions from cottage industries and trading. Wheat, paddy, buckwheat and potatoes are the main agriculture products. Due to low level of agricultural production, the majority of the households face acute food shortages for the large part of the year. The different municipalities of the district are classified as highly and moderately food insecure region ${ }^{1}$.

${ }^{1}$ NeKSAP 2016. Nepal Food Security Monitoring System. Ministry of Agricultural Development (MoAD) and World Food Programme (WFP). 

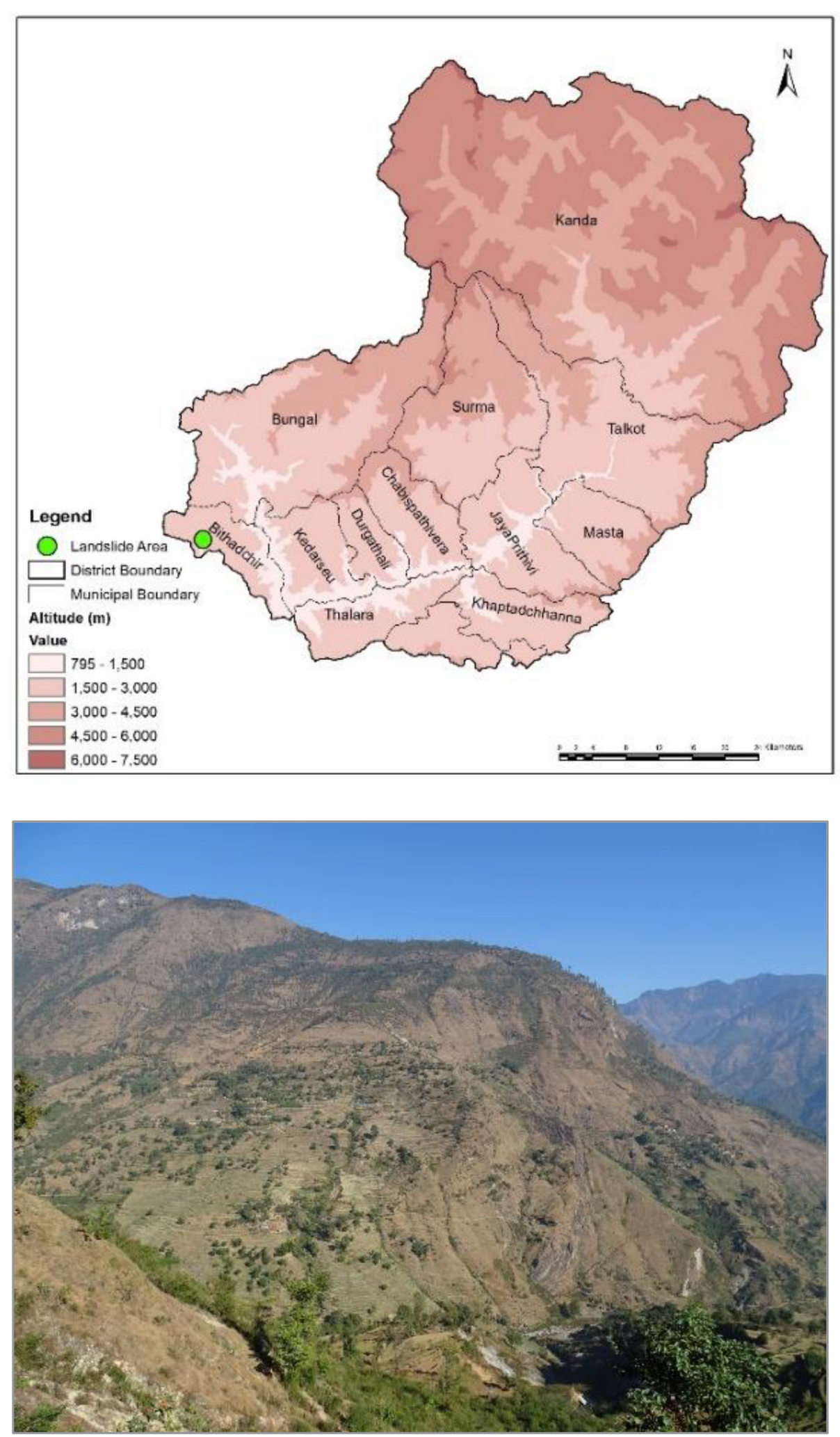

FIGURE 1| The Sunkuda Landslide in Bajhang. 

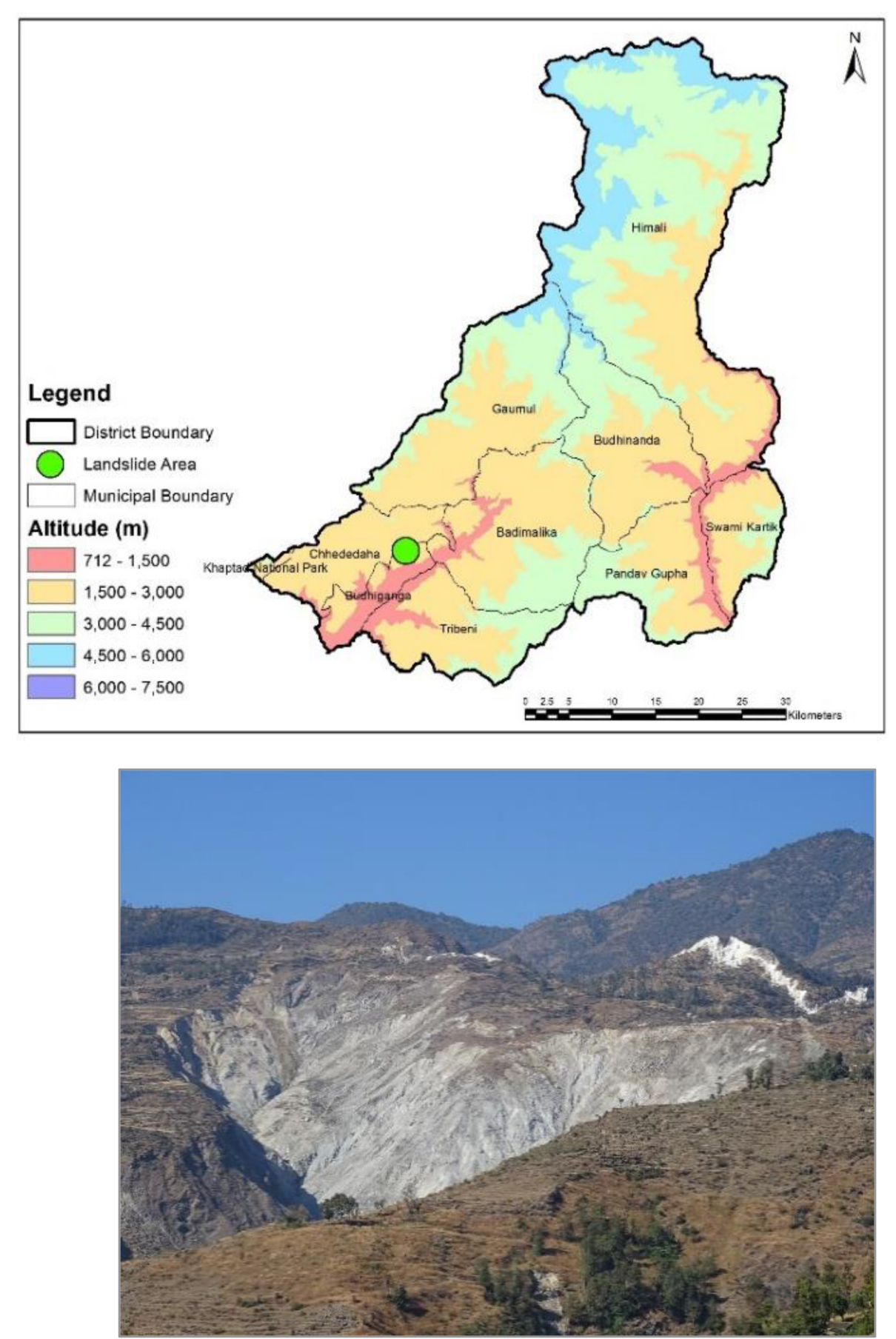

FIGURE 2 | The Bajedi landslide in Bajura.

Overall, the economic condition of the district is poor; with the average income per person is Rs. 3,428 per month ${ }^{2}$. According to the District Disaster Preparedness Plan, this district is highly vulnerable to the natural hazards. The most occurring hazards are floods, landslides, hailstorm, lightening, drought and earthquake.

${ }^{2}$ National Census 2011. Central Bureau of Statistics, Nepal.

\section{RESULTS}

\section{Existing Local Strategies}

From the interviews we distilled a variety of strategies that local people rely on to maintain and advance their livelihoods in very challenging circumstances. These strategies are represented in Table 3 and vary along the dimension 


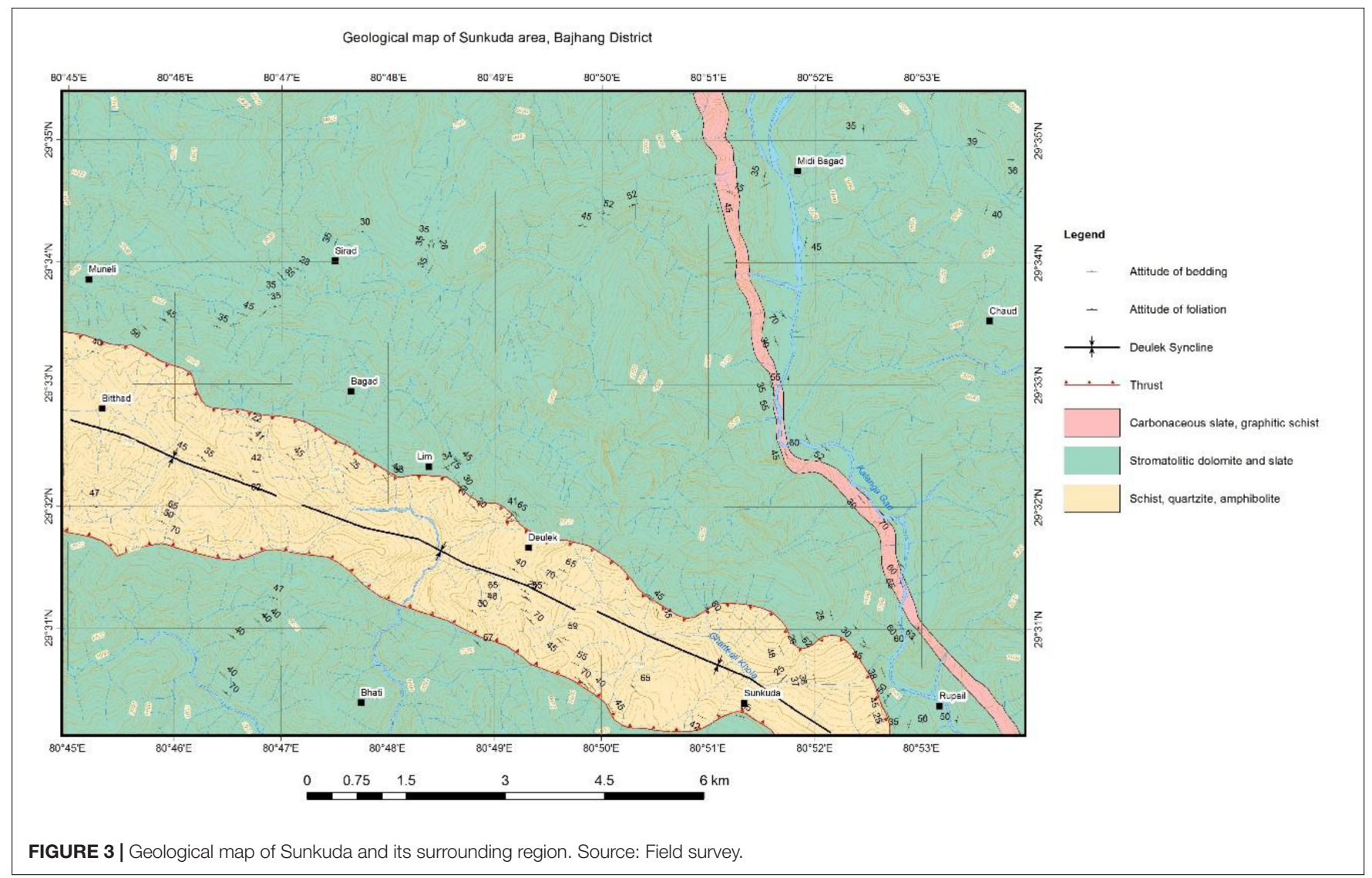

from absorptive to adaptive to transformative strategies (Mao et al., 2017).

The experiential knowledge base about landslides is everexpanding: performing the daily farming tasks (fetching water, getting fodder and timber) in the landslide season (monsoon) being highly dependent on vigilant observation. Common sense harbingers of landslide activity, like rapid increases in stream turbidity, precipitation intensity, incipient movement of slope materials, and appearance of new fissures on hillslopes are carefully studied to assess risk. As a result, in the living memory of the inhabitants only one person from the slope settlements ever died in the landslide event, the other two fatalities being outsiders visiting the village.

While losing one's home is certainly a blow, the traditional construction systems permit easy recycling of materials, unless they have degraded badly. The earth walls can be converted back into mud and used for building a new house. The years of close-up vigilant observation of cracks and crevices made the inhabitants of Sunkuda and Bajedi experts in determining whether a house or a farm outbuildings can survive another monsoon. It is land shortage that poses a problem: since no compensation is granted for lost land or property, the only remaining option is relaying on family and kinship networks for shelter up until the next remittance flow.

Both heavily affected households and the ones that have been spared from the most severe impacts (e.g., loss of a house, loss of the agricultural fields) are equally concerned about the recent intensification of the land movement processes. In the absence of formal support, the community members have developed and applied a number of locally available strategies to deal with landslide risk: from banning the grazing of animals from the affected areas, through re-directing water flows away from the landslide are during monsoon, to different afforestation schemes. While some of the measures are considered "mildly successful," the overall efficacy of these strategies is rather low. Agricultural fields are the most affected: the rain-fed bari-land and in particular, the irrigated khat-land terraces crack and fracture, and finally crumble and collapse. Depending on the extent of the damage, they are either considered completely unrestorable, or take weeks of manual labor to repair and prepare for the next sowing season. At the same time, the traditional agricultural base of the livelihood options in our research sites is also considered to be the source of resilience. As opposed to occupations that require equipment or the stocking of merchandise which can be lost in a landslide event, agricultural production may usually continue after the hazard occurs, albeit at a smaller scale or in a far-off location.

Switching to new, more resistant crop varieties that produce more yield in the eroded terrain is a common strategy, supported by the Nepalese agricultural extension services. The role of livestock in the household production cycle has also changed: previously considered to be mainly manure producers (a large 


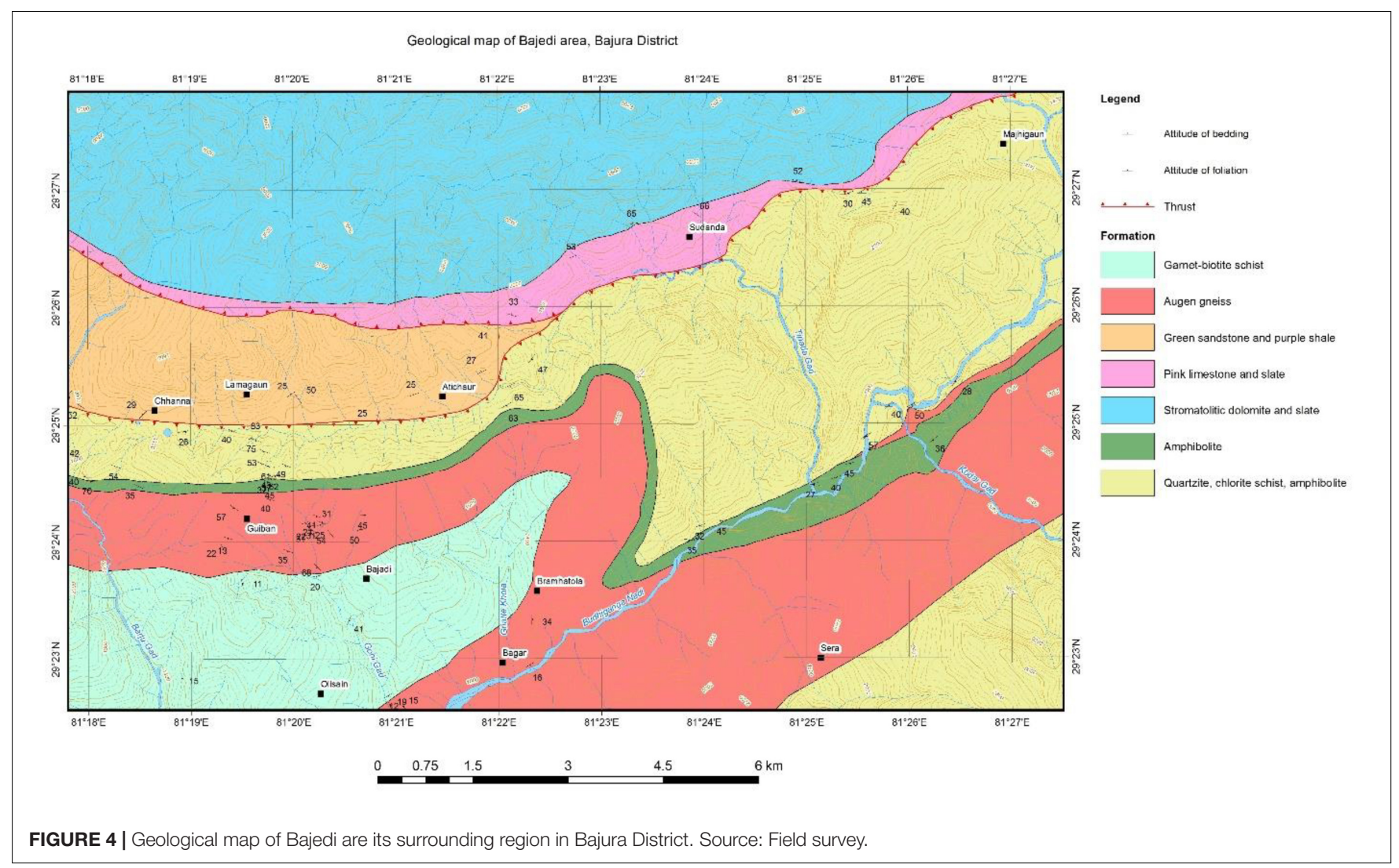

proportion of the Sunkuda and Bajedi settlements do not consume meat for traditional and spiritual reasons), livestock is now reared and sold for cash as there are not enough fields to use up all the manure.

In response to the impacts of landslides on agriculture, most of the affected households choose to diversify their livelihood options: by starting a trade or seeking wage employment in services. These jobs, however, are in short-supply, and as more and more land is lost with each monsoon, the only remaining option is outmigration. In our study areas, the respondents declared that every single household has at least one person working in neighboring India or one of the Gulf Countries, and the remittances they generate are in fact the only steady cash flow to the villages. This is in line with the recent research findings which reveal that at least three quarters of the households in Western Nepal have at least 1 working abroad migrant (Jaquet et al., 2015, 2016). The average remittance cash flow was estimated to be US\$ 206 per month and used mainly for basic need fulfillment (food and goods) and for investment in agriculture.

\section{Decision-Making Process Unfolded - Challenges of Outmigration and Policy Response}

The responses of our interviewees reveal a wide array of strategies that the inhabitants of Sunkuda and Bajedi have been applying over the years in order to manage their uncertain livelihoods. At the same, even though some of them are considered effective in managing the risk, they are not seen as warrantors of community survival in the long run.

When tracing the household trajectories of the affected households, two strategies form an universal pattern. These are reliance on kinship networks (family and neighbors) and outmigration (Figure 5). Interestingly, there two strategies are partly at odds with one another: leaving the village means weakening the kinship bonds and opting out of social networks.

Recent research findings confirm that water-induced hazards are the key driver of labor migration for nearly $80 \%$ household in the Nepalese Himalayas (Banerjee et al., 2011; Gautam, 2017), having a negative effect on both the migrants and the populations left behind. Studies in other parts of Nepal have found that migration has a negative effect on agriculture in the form of labor shortages and land abandonment (Adhikari and Hobley, 2011). Distorted family life, shortage of labor in the village and exacerbated inequalities are among the key drivers of social disintegration and further impoverishment (Chapagain and Gentle, 2015; Jaquet et al., 2016; Sapkota et al., 2016). Labor migrants are also not likely to be better off themselves, because they lack the social ties, education, and resources required to overcome the administrative and monetary constraints on the way to better and more secure jobs (Gautam, 2017).

Apart from the socio-economic effects of population shifts, our findings also reveal the mutually reinforcing connection between outmigration and increased landslide occurrence. 
TABLE 3 | Existing local strategies, example quotes by various informants.

Strategy
Daily observations/means of calculating
risk
Shifting endangered households
upward (moving house)
Seasonal shifting (having two houses or
constructing temporary housing for the
time of the monsoon in a safer place)
Changing role of livestock: from manure
providers to meat cash

Crop diversification and/or intensification

Redirecting active streams away from the landslide site

Afforestation

Employment diversification

Relying on kinship and family ties

Outmigration

\section{Example quote from informants}

(...) If the outside surrounding is very menacing then we do not walk out much, we wait until the rain stops. If it is crucial to go outside and make sure, watch carefully, then we guess if it is okay or not by looking at the land/surrounding environmental condition. We are always alert and cautious; aware that even if we have some urgent errands to run, we should first measure the outside situation. No work is more important than our life, isn't it? (...) Thalamel Tole, Budiganga, Bajura

(...) What can we do when our house is swept away by landslide and there is no place for us to live? We don't have any other alternative expect that moving to safer temporary places. When our houses and the surrounding areas starts getting cracks, that is when we know it is risky to live in that house. Then we move to safer place for shelter. (...) Guiban, Chhededaha, Bajura

(...) There are a total of 41 households in our village of which five households have moved away. The houses have cracked but we put a roof so that we can live temporarily here in winter. There are three, no, four households who live here during winter and elsewhere in monsoon season. (...) Gumla, Chhededaha, Bajura

(...) There is no meaning keeping more livestock when there are no family members to look after it and when there is shortage of fodder, water and everything. In our fields we use the manure from our cattle only but the proportion of land has reduced due to landslide, so we don't need more manure! Sadly, we have less land which means less grasses to feed the cattle therefore we keep less livestock (...) Gumla, Chhededaha, Bajura (...) So, now we rear the cattle/goats and sell them in order to get money for our immediate food and other basic needs (.. . ) Gumla, Chhededaha, Bajura (...) In the past we used to cultivate a breed of paddy known as "Jodan" but since it did not give a desired/sufficient yield we stopped cultivating that breed. I think the reasons behind low productivity these days are because our fertile lands/fields have been swept away by the landslide and erosions and there is decrease in rainfall as well. These days we use new variety of paddy. Some of the crops varieties are recommended by the agriculture officials while we also experiment on our own by seeing it from the nearby villages. (...) Nimani, Budiganga, Bajura

(...) During monsoon, because of the rainfall, the water outflow increases to which we, the villagers, respond by diverting such water away from the landslide affected area. If it isn't done then it can cause the cracks coming down here in our village to aggravate the landslide. So as a preventive measure, we divert the rainwater effluence to other side of the village by making a canal to flow such excessive water. (...) Guiban, Chhededaha, Bajura

(...) We ourselves, the people of this community, started planting trees which was successful to have turned into a community forest later on. So this is one of the efforts the locals have done to fight against this adversity, or to lessen the adversity of landslide. Also, we have restricted grazing cattle in open fields and forest. (...) Nimani, Budiganga, Bajura (...) We have tried several afforestation programs from our side but since we have to plant the tree saplings in monsoon season and the landslide occurs more during that time, the mission has not been successful at all. Adhikari Tole/Dalit Tole, Kadagaun, Bitthadchir, Bajhang

(...) So in order to fulfil the basic needs throughout the year people are engaged in some sort of employment. Majority of people are involved or employed within the village, some work as teachers, and other people have different occupation, making things, services, making do. We have these people, they are engaged in other occupations here, so, overall, everything is well in our village. (...) Thuma, Budiganga, Bajura

(...) My house is in the peak of this landslide. I've no hope of living there. I don't want to leave my brothers so I'll move to the land that belongs to me along with my brothers. (...) Gumla, Chhededaha, Bajura

(...) People from our village do go out of the country to get better job opportunities. The male population of our village mainly goes to India to work as laborers for about 5-6 months each year. It is seasonal. But what else can we do, we need employment to survive. We cannot make a living by staying in this village and also we cannot just depend upon the outcome from agriculture in a risky place like this. Our land is going! Washed away. Therefore, by Baishak (April-May) we leave to India for jobs. We have 83 households in this village where every 2-3 men per house go to India for employment. Only the children and women stay behind, to look after our homes, and what is left of crops and cattle. (...) Guiban, Chhededaha, Bajura One member of each household goes to India for employment and they return after $2-4$ years. We are surviving based on the income of this one member of our families because they are earning money by doing jobs in India; otherwise the crops that we grow, this food isn't even enough for more than 2-3 months (. . .). (After the latest landslide) we do not have the seeds of wheat to sow for this year. Barbelka, Bitthadchir, Bajhang
Though in literature, outmigration is usually seen as the effect of landslides, we find that it is also the root cause: migrants leave behind arable land (terraces) that the remaining household members are no longer able to sustain. It is in fact this abandoned land (in particular, the irrigated Khat-land) that is considered to be the most landslide-prone (Figure 6). Formerly irrigated terraces, once collapsed, deteriorate into open landslide much faster than any other type of land cover (including over-grazed pastures and deforested hills). A vicious cycle is formed, where outmigration is driven by the hazard, resulting in decrease in uphill land management, which in turn exacerbates shallow landslips (Gerrard and Gardner, 2002; Munroe et al., 2013; Sapkota et al., 2016; Ojha et al., 2017).

At the same time, outmigration of just one family member often allows the left-behind family to move to another location (to more stable uphill land for house construction or to the fertile downhill land in the river valleys). Though not sustainable in the long-term, remittances from outmigration allow the households to remain relatively food-secure and often enable the younger household members to access education and occupational training opportunities (see e.g., Marino and Lazrus, 2015). 


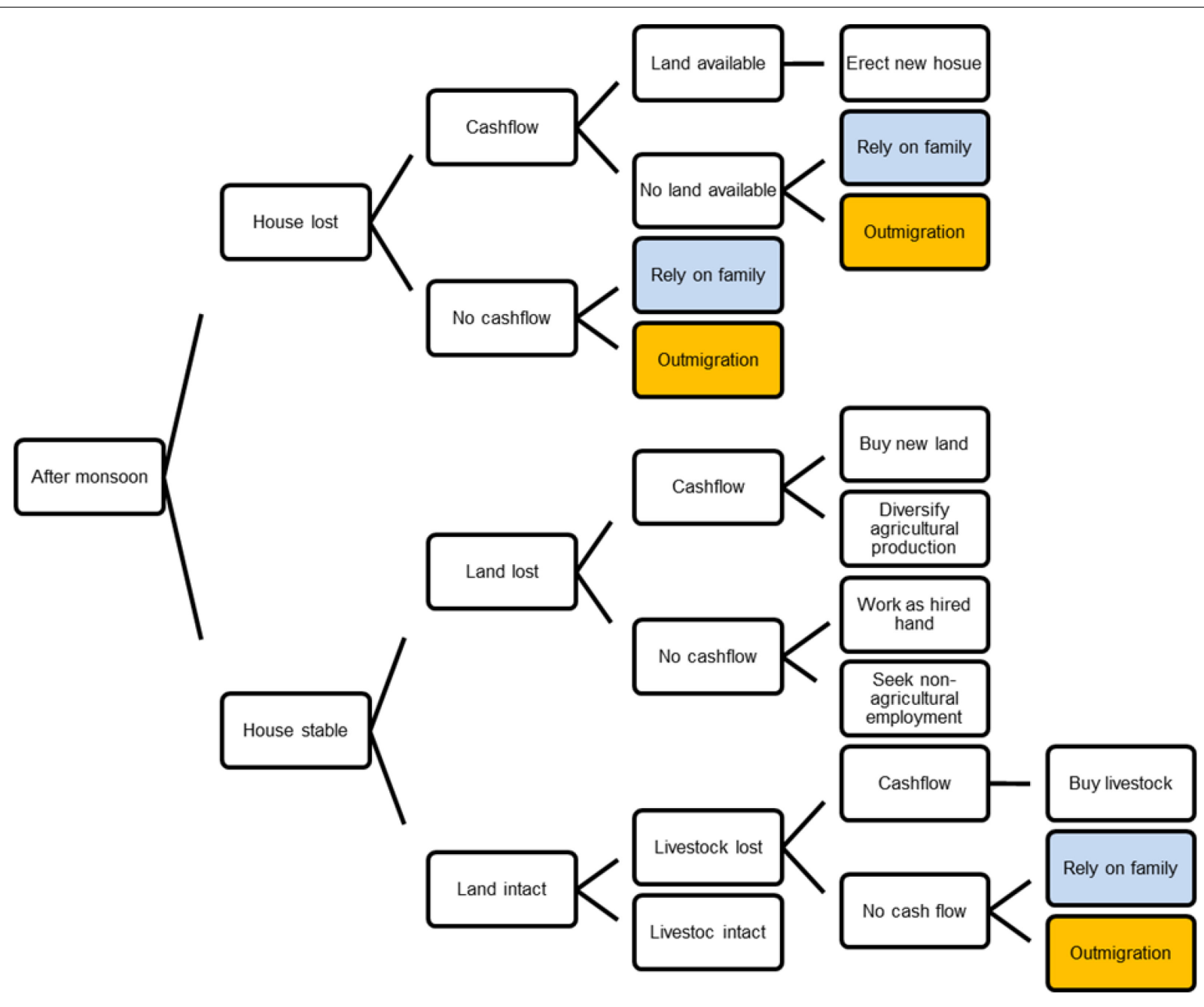

FIGURE $\mathbf{5}$ | Decision making process.

\section{Potential for Citizen Science}

As previously stated, local knowledge is key to increasing resilience to chronic landslide hazards. However, to date, it has not been fully harnessed by practitioners and policy-makers (Hiwasaki et al., 2014). In this part of the paper we explain how citizen science approaches can help integrate local knowledge with science and technology, making it useful for policies, education, and actions related to disaster risk reduction.

\section{Participatory Science, Participatory Environmental Monitoring, Virtual Citizen Science}

Citizen science emerged and gained popularity in the Western academe as a result of a rapid expansion of information and communication technologies (ICTs) (Haklay M., 2013). Scientists in various disciplines, in particular, ecology and conservation scholars, discovered the potential to cut the costs of research and bring their projects to scale: by mobilizing volunteers to collect environmental observations (bird counting, taking water samples) and sending them via their ICT devices to an online database, they were able to obtain panel data of unprecedented scope and scale (Liebenberg et al., 2017; Cieslik et al., 2018). This became known as participatory environmental monitoring: engaging the citizens in collecting observations that help scientists build better models.

Around the same time, a new source of geographic information has become available in the form of user-generated online content, supported by technologies known as Web 2.0 (Goodchild, 2007; Elwood et al., 2012). Also referred to as participatory internet or the social web, Web 2.0 denotes a wide range of interactive websites that emphasize usability, democratic access and interoperability (Haklay et al., 2008). In particular, the launch of Google Maps and Google Earth, both opensource and user friendly, popularized the use of geospatial data by the public. Some examples of user-generated geo-referenced data repositories include GeoCommons, OpenStreetMap and Wikimapia (Coleman et al., 2009; Meier et al., 2012). Making high-resolution satellite data freely available to the general public (Natural Earth Data, Esri Open Data, USGS Earth Explorer, etc.) opened new possibilities for science-society collaborations, allowing the scientists to harness the work power of hundreds 


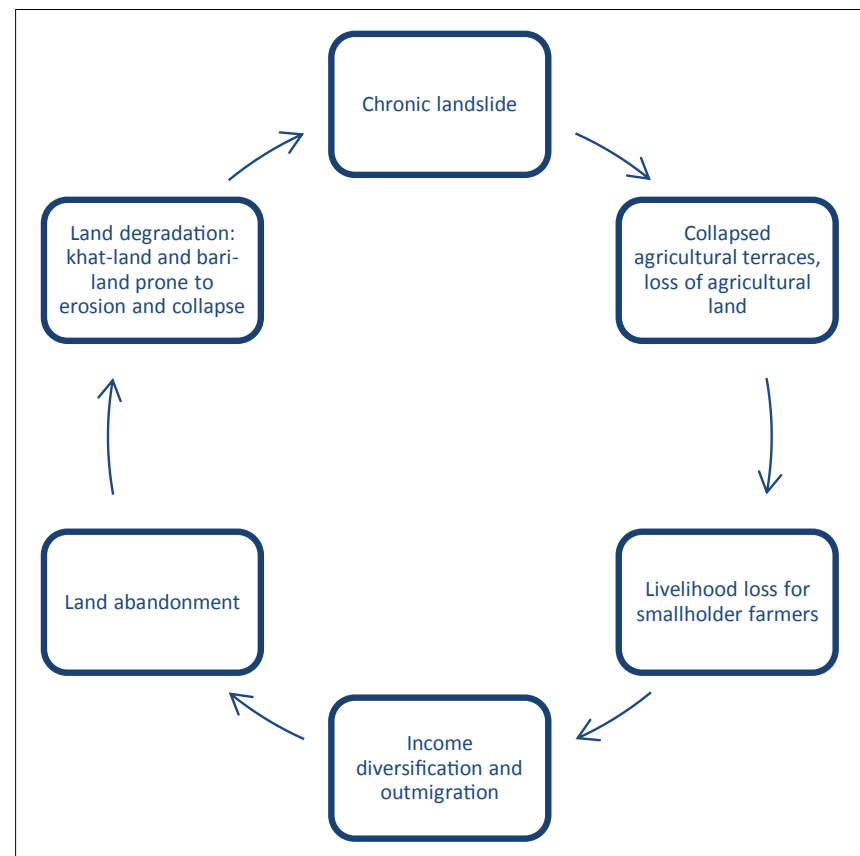

FIGURE 6 | Landslide and livelihoods cycle.

of volunteers around the globe to create and analyze big data (Hong et al., 2007; Farahmand and Aghakouchak, 2013). Recognized as "neogeography," these initiatives were quickly integrated in both science (data crowdsourcing) and public benefit organizations (monitoring and accountability) (Liu and Palen, 2010; Haklay M.M., 2013). Contrary to the environmental and conservation science initiatives, neogeographers are often physically completely disconnected from the reality that they are mapping, which is why we choose to term them "virtual" citizen scientists (see also De La Ville et al., 2002; Table 3).

In the development context, including local stakeholders in the research process dates back to the early 1970s. Robert Chambers and Paul Freire are among the many participatory development scholars of who argued that in order to put the marginalized at the center of the processes of development policy, they need to first be included in development research (Wisner, 2006). Contrary to citizen science, which is geared toward big data and scientific modeling, participatory research in development (including participatory rural appraisal, participatory action research and "community science") was always very context specific and focused on addressing a pressing local issue with the concerned local stakeholders (Table 3).

Even though, in principle, citizen science is also aimed at addressing pressing social and environmental problem, citizen science projects have a much longer timeframe horizon, extending into several years or even decades (see e.g., the E-Bird project by Cornell University). Due to the often dramatic, near-subsistence socio-economic conditions of the communities in development contexts, mobilizing them for such extensive volunteer work is not very ethical, and in a number of cases, not even possible without monetary compensation or other form of incentive (Hufton, 2017). The projects that have managed to achieve citizen participation in such contexts are often, though original and interesting in design, much more modest in scale and scope (see e.g., the projects of the Extreme Citizen Science ExCite from UCL London) (Table 4).

Against this background, we propose that a successful application of citizen science requires a combination of all three citizen-science sub-categories. In the sections below, we first provide a brief overview of citizen science project in disaster contexts. Then, we explain and give examples of how the different approaches are best suited for different types of social and scientific problems as well as different stakeholder levels.

\section{Citizen Science and Disaster Response}

As described above, citizen science provides a useful approach for both community engagement and low-cost, real-time production of scientific data. As such, they are well suited for disaster contexts, where broad and timely collection and provisioning of information is essential for effective risk management: preparedness, response, recovery, and but also adaptation, mitigation and resilience building. It provides an alternative to traditional top-down information flow and optimize the efforts of relief organizations.

While most of the existing projects are largely considered successful attempts of citizen - scientists integration (Table 1), it should also be noted that a vast majority relies can be classified as "virtual citizen science." They come from two broad categories: volunteered geographic information (VGI), or usergenerated content with geotags (hidden codes that link content to geographic locations) and social media enabled mapping platforms (like Ushahidi or CrisisMappers that link up with Facebook and Twitter feeds) (Coleman et al., 2009; Gao et al., 2011). While extremely useful in facilitating the on-the-ground work (monitoring and coordinating relief progress, improving, accuracy and security), these approaches do not necessarily build on local knowledge and capacities. The idea of recognizing locallevel stakeholders as informed experts of their own environments does not fit in with technology-driven paradigm of algorithms and big data. In the next section, we describe an attempt of a more engaged approach in the case studies of our project.

\section{Starting Citizen Science Activities in the Study Sites}

The Citizen Science in Schools (CSIS) program that has just started in the two case-study sites was designed around the core concepts of (i) integrating local knowledge with science and technology to make it useful for policy, education and action, and (ii) to increase resilience in remote communities. Two schools were selected in the field sites, one each in Bajhang and Bajura, with children attending aged from 10 to 16 . These schools were selected on the basis of hazard proximity (landslides), their facilities (electricity, cellular phone reception), and willingness of staff to participate on a long-term basis. The criteria provided a platform for highly contextualized citizen science activities to be designed that built upon the participants' knowledge of how local hazards affected their day to day lives, deepened understandings of Landslide-EVO activities at their school and 
TABLE 4 | Citizen-science typology.

\begin{tabular}{|c|c|c|c|c|}
\hline & Category & $\begin{array}{l}\text { Participatory science } \\
\text { (community science) }\end{array}$ & $\begin{array}{l}\text { Participatory environmental } \\
\text { monitoring }\end{array}$ & $\begin{array}{l}\text { Virtual citizen } \\
\text { science }\end{array}$ \\
\hline \multirow[t]{3}{*}{ Why? } & Disciplinary origin & $\begin{array}{l}\text { Development studies and } \\
\text { anthropology }\end{array}$ & Ecology & Geography/GIS \\
\hline & Principal area of application & The Global South & The Global North & International \\
\hline & Objective & Empowering the subaltern & $\begin{array}{l}\text { Scaling/cost cutting - doing } \\
\text { science }\end{array}$ & Scaling/cost cutting \\
\hline \multirow[t]{8}{*}{ How? } & Participant motivation & Addressing a pressing problem & Contribution to science & $\begin{array}{l}\text { Satisfaction, } \\
\text { curiosity }\end{array}$ \\
\hline & Range & Site-Specific & Site specific & Global \\
\hline & Relationship & Embedded, engaged & Embedded, engaged & Detached \\
\hline & Situation & On-site & On-site & Remote \\
\hline & Time horizon & Short & Long & Long \\
\hline & Transaction cost & Medium & High & Low \\
\hline & Role of technology & Marginal & Amplifier & Enabler \\
\hline & Mode & Real-life & Real-life & Virtual/cyber \\
\hline \multirow[t]{2}{*}{ Examples } & Example projects/approaches & $\begin{array}{l}\text { Participatory Rural Appraisal (PRA); } \\
\text { Community Based Project } \\
\text { Management }\end{array}$ & E-Bird & $\begin{array}{l}\text { Open Street } \\
\text { Mapping (OSM) }\end{array}$ \\
\hline & Notable scholars & Paulo Freire, Robert Chambers & Muki Haklay, Rick Bonney & Steve Coast \\
\hline
\end{tabular}

in the surrounding area, and enriched the project's qualitative database. Both schools had Landslide-EVO low cost rain gauges installed in their grounds in early 2018. The initial lesson took place in May 2019 and was focused on monsoonal precipitation patterns and their relationship with chronic landslides in the area. Both classes' students demonstrated prior knowledge about the connection between monsoonal rainfall and increased seasonal landslide occurrence.

Preliminary observations from CSIS align with some theoretical assertions surrounding the benefits of citizens science outlined earlier. Thus the intermediate value added from CSIS lesson was to create a common language between the lived experience and more scientized hydrological hazard explanations. This scientific lexicon is then used by students when sharing knowledge of hazard events with their parents and the wider community, increasing resilience through demystification of the hazard (Mercer et al., 2010; Walshe and Nunn, 2012). This initial benefit will be compounded at the homes of selected students through participatory environmental monitoring of precipitation levels for 1-2 years. These data will be sent to Landslide-EVO researchers on a monthly basis via the head teachers of the schools. Additionally, the data will provide verification of readings from previously installed rain gauges in the area as well as increase the spatial and temporal distribution of the data set (Bonney et al., 2009; Buytaert et al., 2014). Future CSIS lessons will explore warning signs of potential hazards, including OSM mapping of landslides and crack monitoring, to build local risk knowledge and provide novel policy relevant data.

\section{Addressing Policy Challenges}

Effective integration of citizen science in development research and policy requires customizing methods and data sources for the specific problem. Here, we are particularly interested in the case of chronic hazards - like the shallow, seasonal landslides in Sunkuda and Bajedi.

Looking back at the three key challenges at national level for effective policy response (underreporting, trivialization of the problem and misinformation, section "The Underestimated Hazard: the Destructive Significance of Seasonal Landslides") we find that the emergent trends in citizen science (in particular, participatory environmental monitoring) hold considerable promise to bring the wealth of local knowledge to scale. Participatory monitoring is a process through which local stakeholders engage in structured collection of observations which are then compiled into comprehensive databases. In this way, the key stakeholders share control over the content, the process and the results of the reporting process. Amplified by technology, in particular, ICT4D, participatory environmental monitoring can help ameliorate the chronic landslide underreporting issue. A good example of such an intervention is the Cooperative Open Online Landslide Repository (COOLR) - a NASA-led, online spatial analytics platform that allows individual citizen observers to report a landslide occurrence anywhere on the globe. Gradual build-up of the database should in turn draw attention to the staggering scale of the land loss problem, triggering timely and appropriate government response (Petley et al., 2005).

Involving key stakeholders in the knowledge co-production process may in turn help demystify the many misconceptions about the efficacy of the various mitigation measures at the level of regional governments. Observing, documenting and classifying local environmental knowledge about the immediate environment may help tease-out key factors that make particular preventive practices work in one locality and fail in another.

Building landslide resilience requires precise, real-time hazard estimates for the spatial distribution of future landslides, their temporal frequency and intensity. This can be achieved with 
the help of virtual citizen science (Cyber Science): an approach where volunteers around the globe perform detailed analyses of the existing databases, looking for spatiotemporal patterns and building prediction models.

\section{DISCUSSION AND CONCLUSION}

In this paper, we presented a case study of two mountain communities dealing with a chronic landslide hazard. We identified and categorized the strategies employed by the inhabitants of Sunkuda and Bajedi to manage their livelihoods on ever-shrinking land. These strategies reveal a wealth of experiential knowledge that should be integrated in responsive policy making. This is in line with findings in Cameroon and Uganda (Kervyn et al., 2015), where a broad range of relevant landslide resilience strategies were derived from focus group meetings with stakeholders. Our finding that seasonal migration is a livelihood strategy for remote communities in Nepal is in line with Gautam (2017), but we add insights on how landslides interplay with migration dynamics, building upon earlier studies on this topic, like Sudmeier-Rieux et al. (2012).

When trying to navigate the complexities of living with a chronic hazard, the effective application of either adaptation or mitigation measures is not enough: finding a balance between persistence and flexibility is key to achieving relatively resilient living. Accordingly, both the merits and tradeoffs of the different strategies need to be considered in order to develop an appropriate policy response. Sustainable and responsible planning should include hazard mapping, in particular, slope susceptibility data and settlement exclusion zones. Also, land accessibility should be carefully reviewed and analyzed as it may reveal why people continue to settle in hazard-prone areas. At the same time, for such research to be of value, it should take into account the unique epistemological viewpoints of the concerned stakeholders: the members of the affected communities as well as the lower governance structures directly involved in regional decision-making.

In our analysis we argue that local knowledge needs to be integrated with science before it can be used in planning, education, and policy. Citizen science provides a useful approach to demonstrating how local knowledge can be used to both anticipate and mitigate hazards, and to support better planning. Even though a number of citizen science projects look for active engagement with individual citizen-volunteers, different forms of citizen science can be more suited for different level stakeholders. While diligently crafted slope susceptibility maps might not be of much use to individual households (i.e., they do not provide information of sufficient granularity or certainty to plan household-level land use), they can provide invaluable planning material for local governance structures (e.g., strategically planning future interventions for the most hazard prone settlements). Similarly, though engaging local-level stakeholders in remote-sensing data analysis might not make much sense (insufficient infrastructure to gather, process and visualize data at local level), national-level officials can both participate in, and benefit from the process (Figure 7).

While some approaches to citizen science attempt to draw a straight line from individual actions or behaviors (e.g., participation) to policy influence, we argue that intermediate outcomes may be equally important. By participating in the scientific process and working hand-in-hand with interdisciplinary scientists, different stakeholders achieve a better understanding of physical and biological processes in their immediate environment and are able to make linkages between previously dissociated phenomena.

Despite these promising insights, it is important to note that the role and validation of local knowledge is determined by interaction between informal and formal institutions different levels. Giving more consideration to the power relations that

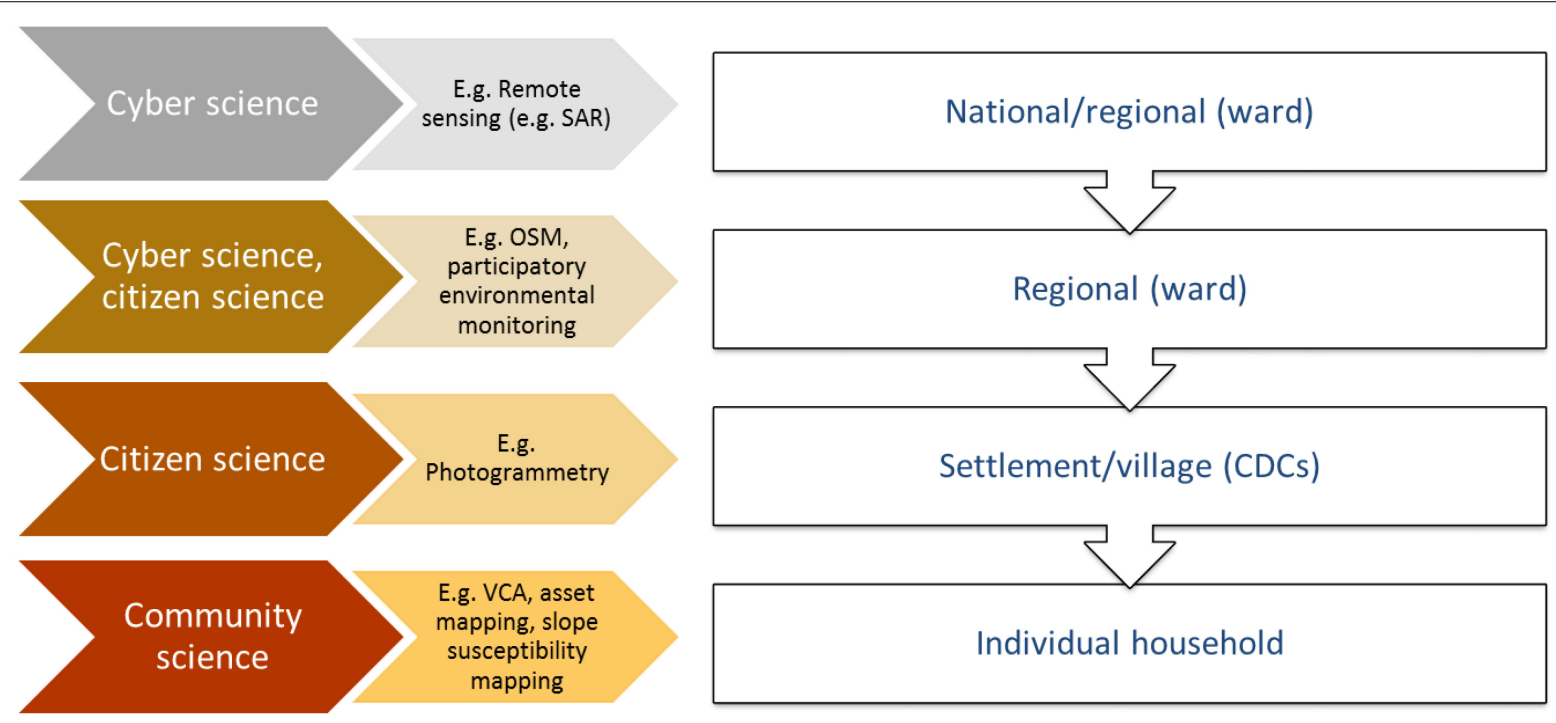

FIGURE 7 | Stakeholder levels for different types of participatory science. 
endorse or invalidate local knowledge is key to correctly identify and address the structural constraints to the use of local knowledge across scales (Naess, 2013).

We fully acknowledge that the theory-building potential of our study is limited. We used non-probability sampling which does not allow for wide generalizations, and our results are very context-specific. At the same time, our findings are consistent across the range of different interviews, with the same recurring topics and causality patterns Further research on other and larger communities and in different contexts would be very valuable to test the generalizability of our findings. We are also not yet in the position to evaluate the citizen science activities implemented within the Landslide-EVO project, as these have only just began in the study sites. By sharing the preliminary insights from the project we follow the tradition of the so called "diagnostic studies" (Hounkonnou et al., 2004; Röling et al., 2004 for more reference). Diagnostic studies tend to provide a situation analysis, followed by a discussion of the feasibility of the proposed intervention (in our case, interdisciplinary citizen-science based activities). Diagnostic studies illustrate the process of developing an understanding of a given social reality and drawing conclusions pertaining to the planned course of action. As such, diagnostic studies are a useful resource for researchers and practitioners alike: they show under what assumptions projects are deployed in a particular site. There are also other limitations that should be acknowledged: researcher bias, social desirability bias and situation bias might have influenced the results and interpretation of the study. At the same time, we attempted to counterbalance these failures with ongoing critical reflection, peer audit and consultations with local partners.

To conclude, we stress that citizen science - based research needs to be individually tailored for specific communities, not only because of the geological and ecological differences between localities but also in consideration of the capabilities and willingness of local governance structures and residents to engage meaningfully with scientists. Due to the chronic nature of the landslide hazards, a very long-term perspective is needed to enable effective modeling, in particular in relation to making predictions and projections. Accordingly, we would

\section{REFERENCES}

Adhikari, J., and Hobley, M. (2011). Everyone Is Leaving-Who Will Sow Our Fields? The Effects of Migration from Khotang District to the Gulf and Malaysia. Kathmandu: Swiss Agency for Development and Cooperation.

Alcántara-Ayala, I. (2004). Flowing mountains in Mexico. Mt. Res. Dev. 24, 10-13. doi: 10.1659/0276-4741(2004)024\\%5B0010:fmim \\%5D2.0.co;2

Arouri, M., Nguyen, C., and Youssef, A. B. (2015). natural disasters, household welfare, and resilience: evidence from rural vietnam. World Dev. 70, 59-77. doi: 10.1016/j.worlddev.2014.12.017

Banerjee, S., Gerlitz, J. Y., and Hoermann, B. (2011). Labour Migration as a Response Strategy to Water Hazards in the Hindu Kush-Himalayas. Kathmandu: ICIMOD.

Barik, M. G., Adam, J. C., Barber, M. E., and Muhunthan, B. (2017). Improved landslide susceptibility prediction for sustainable forest management in an altered climate. Eng. Geol. 230, 104-117. doi: 10.1016/j.enggeo.2017.09.026 like to discourage universal application of citizen science approaches - which have become a buzzword in the development sector - and instead propose a carefully crafted combination of participatory science, citizen science and virtual citizen science. Conceptualized as such, citizen science-based research can prove very effective in providing practical recommendations for households and policy makers at various administrative levels.

\section{AUTHOR CONTRIBUTIONS}

All authors listed have made a substantial, direct and intellectual contribution to the work, and approved it for publication.

\section{FUNDING}

This manuscript was realized within the interdisciplinary interuniversity consortium L-EVO. The authors acknowledge the financial support from the Natural Environment Research Council (NERC) and Department for International Development (DFID) under the United Kingdom Science for Humanitarian Emergencies and Resilience (SHEAR) program (Grant Number NE/P000452/1).

\section{ACKNOWLEDGMENTS}

The fieldwork for this manuscript was made possible thanks to the cooperation between Wageningen University and Practical Action Nepal. The authors are indebted to Practical Action team who made this data collection possible by sharing their insights and facilitating the cooperation with the communities of Bajura and Bajhang. In particular, this research would not have been possible without the assistance of Dinanath Bhandari, Bharat Raj, Saugat Paudel, and Elina Shrestha, to whom the authors extend their warmest gratitude. Last but not least, we would like to thank all of our interviewees for volunteering their time to talk to us and for allowing us to gain insight into their lives.

Barrett, C. B., and Constas, M. A. (2014). Toward a theory of resilience for international development applications. Proc. Natl. Acad. Sci. U.S.A. 111, 14625-14630. doi: 10.1073/pnas.1320880111

Barrios, R. E. (2014). 'Here, I'm Not at Ease': anthropological perspectives on community resilience. Disasters 38, 329-350. doi: 10.1111/disa.12044

Barrios, R. E. (2016). Resilience: a commentary from the vantage point of anthropology. Ann. Anthropol. Pract. 40, 28-38. doi: 10.1111/napa.12085

Béné, C., Mehta, L., McGranahan, G., Cannon, T., Gupte, J., and Tanner, T. (2018). Resilience as a policy narrative: potentials and limits in the context of urban planning. Clim. Dev. 10, 116-133. doi: 10.1080/17565529.2017.1301868

Bonney, R., Cooper, C. B., Dickinson, J., Kelling, S., Phillips, T., Rosenberg, K. V., et al. (2009). Citizen science: a developing tool for expanding science knowledge and scientific literacy. Bioscience 59, 977-984. doi: 10.1525/bio.2009.59.11.9

Bonney, R., Shirk, J. L., Phillips, T. B., Wiggins, A., Ballard, H. L., Miller-rushing, A. J., et al. (2014). Next steps for citizen science. Science 343, 1436-1437. doi: $10.1126 /$ science. 1251554 
Broothaerts, N., Poesen, J., Van Rompaey, A., and Getahun, K. (2012). Spatial patterns, causes and consequences of landslides in the gilgel gibe catchment, ethiopia. Catena 97, 127-136. doi: 10.1016/j.catena.2012.05.011

Brosius, J. P., Lowenhaupt Tsing, A., and Zerner, C. (1998). Representing communities: histories and politics of community-based natural resource management. Soc. Nat. Resour. 11, 157-168. doi: 10.1080/08941929809381069

Buytaert, W., Zulkafli, Z., Grainger, S., Acosta, L., Alemie, T. C., Bastiaensen, J., et al. (2014). Citizen science in hydrology and water resources: opportunities for knowledge generation, ecosystem service management, and sustainable development. Front. Earth Sci. 2:26. doi: 10.3389/feart.2014.00026

Campbell, L. M., and Vainio-Mattila, A. (2003). Participatory development and community-based conservation: opportunities missed for lessons learned? Hum. Ecol. 31, 417-438.

Chapagain, B., and Gentle, P. (2015). Withdrawing from agrarian livelihoods: environmental migration in Nepal. J. Mt. Sci. 12, 1-13. doi: 10.1007/s11629014-3017-1

Che, V. B., Kervyn, M., Ernst, G. G. J., Trefois, P., Ayonghe, S., Jacobs, P., et al. (2011). Systematic documentation of landslide events in Limbe area (Cameroon): their geometry, sliding mechanism, controlling and triggering factors. Nat. Hazards 59, 47-74. doi: 10.1007/s11069-011-9738-3

Chu, H. J., and Chen, Y. C. (2018). Crowdsourcing photograph locations for debris flow hot spot mapping. Nat. Hazards 90, 1259-1276. doi: 10.1007/s11069-0173098-6

Cieslik, K. J., Leeuwis, C., Dewulf, A. R. P. J., Lie, R., Werners, S. E., Wessel, M., et al. (2018). Addressing socio-ecological development challenges in the digital age: exploring the potential of environmental virtual observatories for connective action (EVOCA). NJAS Wageningen J. Life Sci. 86-87, 2-11. doi: 10.1016/j.njas.2018.07.006

Cochran, E. S., Lawrence, J. F., Christensen, C., and Jakka, R. S. (2009). The quakecatcher network: citizen science expanding seismic horizons. Seismol. Res. Lett. 80, 26-30. doi: 10.1785/gssrl.80.1.26

Cohen, D., and Schwarz, M. (2017). Tree-root control of shallow landslides. Earth Surf. Dynam. 5, 451-477. doi: 10.5194/esurf-5-451-2017

Coleman, D. J., Georgiadou, Y., Labonte, J., Observation, E., and Canada, N. R. (2009). Volunteered geographic information: the nature and motivation of produsers ${ }^{\circledR}$. Int. J. Spat. Data Infrastruct. Res. 4, 332-358.

Cox, R. S., and Perry, K. M. E. (2011). Like a fish out of water: reconsidering disaster recovery and the role of place and social capital in community disaster resilience. Am. J. Commun. Psychol. 48, 395-411. doi: 10.1007/s10464-0119427-0

Cruden, D. M., and Varnes, D. J. (1996). Landslide Types and Processes. Landslides: Investigation and Mitigation. Washington, DC: Transportation Research Board.

Davoudi, S. (2018). Just resilience. City Community 17, 3-7. doi: 10.1111/cico. 12281

De La Ville, N., Chumaceiro Diaz, A., and Ramirez, D. (2002). Remote sensing and gis technologies as tools to support sustainable management of areas devastated by landslides. Environ. Dev. Sustain. 4, 221-229.

De Longueville, B., Luraschi, G., Smits, P., Peedell, S., De Groeve, T., and Commission, E. (2010). C itizens as sensors for natural hazards. Geomatica 64, 41-59.

de Milliano, C., Faling, M., Clark-Ginsberg, A., Crowley, D., and Gibbons, P. (2015). "Resilience: the holy grail or yet another hype?," in The Humanitarian Challenge, eds P. Gibbons and H.-J. Heintze (Cham: Springer International Publishing), 17-30. doi: 10.1007/978-3-319-13470-3_2

Degrossi, L. C. L., Albuquerque, J. P., de Fava, M. C., and Mendiondo, E. M. (2014). "Flood citizen observatory: a crowdsourcing-based approach for flood risk management in Brazil," in Proceedings of the 26th International Conference on Software Engineering and Knowledge Engineering, São Carlos.

Dekens, J. (2007). Local Knowledge for Disaster Preparedness: A Literature Review. Kathmandu: International Centre for Integrated Mountain Development (ICIMOD).

Dhital, M. R. (2015). “Geology of the Nepal Himalaya," in Regional Perspective of the Classic Collided Orogen. Switzerland: Springer.

Elwood, S., Goodchild, M. F., and Sui, D. Z. (2012). Researching volunteered geographic information: spatial data, geographic research, and new social practice. Ann. Assoc. Am. Geogr. 102, 571-590. doi: 10.1080/00045608.2011. 595657
Farahmand, A., and Aghakouchak, A. (2013). A satellite-based global landslide model. Nat. Hazards Earth Syst. Sci. 13, 1259-1267. doi: 10.1016/j.envsoft.2016. 12.006

Folke, C., Carpenter, S., Elmqvist, T., Gunderson, L., Holling, C. S., and Walker, B. (2002). Resilience and sustainable development: building adaptive capacity in a world of transformations. Ambio 31, 437-440. doi: 10.1579/0044-7447-31.5.437

Folke, C., Carpenter, S. R., Walker, B., Scheffer, M., Chapin, T., Rockström, J., et al. (2010). Resilience thinking: integrating resilience, adaptability and transformability. Ecol. Soc. 15:20.

Gao, H., Barbier, G., and Goolsby, R. (2011). Harnessing the crowdsourcing power of social media for disaster relief. IEEE Intelligent Systems 26, 10-14. doi: 10. 1109/MIS.2011.52

Gardner, J., and Dekens, J. (2007). Mountain hazards and the resilience of socialecological systems: lessons learned in India and Canada. Nat. Hazards 41, 317-336. doi: 10.1007/s11069-006-9038-5

Gautam, Y. (2017). Seasonal migration and livelihood resilience in the face of climate change in Nepal. Mt. Res. Dev. 37, 436-445.

Gaventa, J., and Barrett, G. (2010). So What Difference Does It Make? Mapping the Outcomes of Citizen Engagement. Falmer: University of Sussex.

Gentle, P., and Maraseni, T. N. (2012). Climate change, poverty and livelihoods: Adaptation practices by rural mountain communities in Nepal. Environ. Sci. Policy 21, 24-34. doi: 10.1016/j.envsci.2012.03.007

Gerrard, J., and Gardner, R. (2002). Relationships between landsliding and land use in the likhu khola drainage basin. Middle Hills Nepal 22, 48-55. doi: 10.1659/0276-4741(2002)022\%5B0048:rblalu\%5D2.0.co;2

Glade, T. (2003). Landslide occurrence as a response to land use change: a review of evidence from New Zealand. Catena 51, 297-314. doi: 10.1016/s0341-8162(02) 00170-4

Glade, T., and Crozier, M. (2005). "The nature of landslide hazard impact," in Landslide Hazard and Risk, eds M. Glade and M. Anderson Crozier (Hoboken, NJ: John Wiley), 43-74.

Goodchild, M. F. (2007). Citizens as voluntary sensors: spatial data infrastructure in the world of Web 2.0. Int. J. Spat. Data Infrastruct. Res. 2, 24-32.

Goodchild, M. F., and Glennon, J. A. (2010). Crowdsourcing geographic information for disaster response: a research frontier. Int. J. Digit. Earth 3, 231-241. doi: 10.1080/17538941003759255

Guzzetti, F. (2000). Landslide fatalities and the evaluation of landslide risk in Italy. Eng. Geol. 58, 89-107. doi: 10.1016/s0013-7952(00)00047-8

Guzzetti, F., Cesare, A., Cardinali, M., Fiorucci, F., Santangelo, M., and Chang, K. (2012). Earth-science reviews landslide inventory maps: new tools for an old problem. Earth Sci. Rev. 112, 42-66. doi: 10.1016/j.earscirev.2012.02.001

Guzzetti, F., Peruccacci, S., Rossi, M., and Stark, C. P. (2008). The rainfall intensityduration control of shallow landslides and debris flows: an update. Landslides 5 , 3-17. doi: 10.1007/s10346-007-0112-1

Haklay, M. (2013). "Citizen science and volunteered geographic information: overview and typology of participation," in Crowdsourcing Geographic Knowledge, eds D. Sui, S. Elwood, and M. Goodchild (Dordrecht: Springer).

Haklay, M., Singleton, A., and Parker, C. (2008). Web map- ping 2.0: the neogeography of the GeoWeb. Geogr. Compass 2, 2011-2039. doi: 10.1111/j. 1749-8198.2008.00167.x

Haklay, M. M. (2013). Neogeography and the delusion of democratisation. Environ. Plan. A 45, 55-69. doi: 10.1068/a45184

Hassanzadeh, R., and Nedovic-Budic, Z. (2014). Assessment of the contribution of crowd sourced data to post-earthquake building damage detection. Int. J. Inform. Syst. Crisis Response Manag. 6, 1-37. doi: 10.4018/ijiscram.2014010101

Heckathorn, D. D. (2011). Comment: snowball versus respondent-driven sampling. Sociol. Methodol. 41, 355-366. doi: 10.1111/j.1467-9531.2011.01 244.x

Hermelin, M., and Bedoya, G. (2008). Community participation in natural risk prevention: case histories from Colombia. Geol. Soc. Lond. Spec. Public. 305, 39-51. doi: 10.1144/sp305.5

Hilley, G. E., Bürgmann, R., Ferretti, A., Novali, F., and Rocca, F. (2004). Dynamics of slow-moving landslides from permanent scatterer analysis. Science 304, 1952-1955. doi: 10.1126/science.1098821

Hiwasaki, L., Luna, E., and Shaw, R. (2014). Process for integrating local and indigenous knowledge with science for hydro-meteorological disaster risk reduction and climate change adaptation in coastal and small island 
communities. Int. J. Disaster Risk Reduct. 10, 15-27. doi: 10.1016/j.ijdrr.2014. 07.007

Hong, Y., Adler, R., and Huffman, G. (2007). Use of satellite remote sensing data in the mapping of global landslide susceptibility. Nat. Hazards 43, 245-256. doi: 10.1007/s11069-006-9104-z

Hounkonnou, D., Offei, S. K., Roling, N. G., Tossou, R., van Huis, A., Struik, P. C., et al. (2004). Diagnostic studies: a research phase in the convergence of sciences programme. NJAS Wageningen J. Life Sci. 52, 3-4.

Hufton, A. (2017). Author's corner: providing incentives and ensuring quality in citizen science. Scientific Data Updates. Available at: http://blogs.nature.com/scientificdata/2017/06/13/authors-corner-providingincentives-and-ensuring-quality-in-citizen-science/

Jacobs, L., Kabaseke, C., Bwambale, B., Katutu, R., Dewitte, O., Mertens, K., et al. (2019). The geo-observer network: a proof of concept on participatory sensing of disasters in a remote setting. Sci. Total Environ. 670, 245-261. doi: 10.1016/j. scitotenv.2019.03.177

Jalbert, K., and Kinchy, A. J. (2015). Sense and influence: environmental monitoring tools and the power of citizen science. J. Environ. Policy Plan. 18, 379-397. doi: 10.1080/1523908x.2015.1100985

Jaquet, S., Schwilch, G., Hartung-hofmann, F., Adhikari, A., and Sudmeier-rieux, K. (2015). Does outmigration lead to land degradation? Labour shortage and land management in a western Nepal watershed. Appl. Geogr. 62, 157-170. doi: 10.1016/j.apgeog.2015.04.013

Jaquet, S., Shrestha, G., Kohler, T., and Schwilch, G. (2016). The effects of migration on livelihoods, land management, and vulnerability to natural disasters in the harpan watershed in Western Nepal. Mt. Res. Dev. 36, 494-505. doi: 10.1659/ mrd-journal-d-16-00034.1

Kervyn, M., Jacobs, L., Maes, J., Che, V. B., and De Hontheim, A. (2015). Landslide resilience in equatorial Africa: moving beyond problem identification. Belgian J. Geogr. 1, 1-19.

Kirschbaum, D., Stanley, T., and Zhou, Y. (2015). Spatial and temporal analysis of a global landslide catalog. Geomorphology 249, 4-15. doi: 10.1016/j.geomorph. 2015.03.016

Kirschbaum, D. B., Adler, R., Hong, Y., Hill, S., and Lerner-Lam, A. (2010). A global landslide catalogue for hazard applications: method, results, and limitations. Nat. Hazards 52, 561-575. doi: 10.1007/s11069-009-9401-4

Lacasse, S., and Nadim, F. (2009). "Landslide risk assessment and mitigation strategy," in Landslides - Disaster Risk Reduction, eds K. Sassa and P. Canuti (Berlin: Springer), 31-61. doi: 10.1007/978-3-540-69970-5_3

Le Coz, J., Patalano, A., Collins, D., Guillén, N. F., García, C. M., Smart, G. M., et al. (2016). Crowdsourced data for flood hydrology: feedback from recent citizen science projects in argentina, france and New Zealand. J. Hydrol. 541, 766-777. doi: 10.1016/j.jhydrol.2016.07.036

Leeuwis, C., Cieslik, K. J., Aarts, M. N. C., Dewulf, A. R. P. J., Ludwig, F., Werners, S. E., et al. (2018). Reflections on the potential of virtual citizen science platforms to address collective action challenges: lessons and implications for future research. NJAS Wageningen J. Life Sci. 86-87, 146-157. doi: 10.1016/j. njas.2018.07.008

Liang, W. T., Lee, J. C., Chen, K. H., and Hsiao, N. C. (2017). Citizen earthquake science in Taiwan: from science to hazard mitigation. J. Disaster Res. 12, 1174-1181. doi: 10.20965/jdr.2017.p1174

Liebenberg, L., Steventon, J., Brahman, N., Benadie, K., Minye, J., Langwane, H., et al. (2017). Smartphone icon user interface design for non-literate trackers and its implications for an inclusive citizen science. Biol. Conserv. 208, 155-162. doi: 10.1016/j.biocon.2016.04.033

Liu, S. B., and Palen, L. (2010). the new cartographers: crisis map mashups and the emergence of neogeographic practice sophia B. Cartography 37, 69-90. doi: 10.1559/152304010790588098

Maes, J., Mertens, K., Jacobs, L., Bwambale, B., Vranken, L., Dewitte, O., et al. (2019). Social multi-criteria evaluation to identify appropriate disaster risk reduction measures: application to landslides in the Rwenzori Mountains, Uganda. Landslides 16, 1793-1807. doi: 10.1007/s10346-0181030-0

Mao, F., Clark, J., Karpouzoglou, T., Dewulf, A., Buytaert, W., and Hannah, D. M. (2017). HESS opinions: a conceptual framework for assessing sociohydrological resilience under change. Hydrol. Earth Syst. Sci. 21, 3655-3670. doi: 10.5194/hess-21-3655-2017

Marchezini, V., Trajber, R., Olivato, D., Muñoz, V. A., de Oliveira Pereira, F., and Oliveira Luz, A. E. (2017). Participatory early warning systems: youth, citizen science, and intergenerational dialogues on disaster risk reduction in Brazil. Int. J. Disaster Risk Sci. 8, 390-401. doi: 10.3390/ijerph14070749

Marino, E., and Lazrus, H. (2015). Migration or forced displacement? the complex choices of climate change and disaster migrants in shishmaref, alaskaand nanumea, tuvalu. Hum. Organ. 74, 341-350. doi: 10.17730/0018-7259-74.4.341

McCormick, S. (2012). After the cap: risk assessment, citizen science and disaster recovery. Ecol. Soc. 17, 31-41.

McKinley, D. C., Miller-Rushing, A. J., Ballard, H. L., Bonney, R., Brown, H., CookPatton, S. C., et al. (2017). Citizen science can improve conservation science, natural resource management, and environmental protection. Biol. Conserv. 208, 15-28.

Meier, P., Cochran, E. S., Lawrence, J. F., Christensen, C., Jakka, R. S., Goodchild, M. F., et al. (2012). Crisis mapping in action: how open source software and global volunteer networks are changing the world, one map at a time. J. Hydrol. 80, 571-590.

Mercer, J., Kelman, I., Taranis, L., and Suchet-Pearson, S. (2010). Framework for integrating indigenous and scientific knowledge for disaster risk reduction. Disasters 34, 214-239. doi: 10.1111/j.1467-7717.2009.01126.x

Miles, M. B., and Huberman, M. A. (1994). Qualitative Data Analysis: An Expanded Sourcebook. London: Sage.

Munroe, D. K., Berkel, D. B., Van Verburg, P. H., and Olson, J. L. (2013). Alternative trajectories of land abandonment: causes, consequences and research challenges. Curr. Opin. Environ. Sustain. 5, 471-476. doi: 10.1016/j. cosust.2013.06.010

Naess, L. O. (2013). The role of local knowledge in adaptation to climate change. Wires Clim. Change 4, 99-106. doi: 10.1002/wcc.204

Ojha, H. R., Shrestha, K. K., Subedi, Y. R., Shah, R., Nuberg, I., Heyojoo, B., et al. (2017). Agricultural land under-utilisation in the hills of Nepal: investigating socio-environmental pathways of change. J. Rural Stud. 53, 156-172. doi: 10.1016/j.jrurstud.2017.05.012

Olsson, L., Jerneck, A., Thoren, H., Persson, J., and O’Byrne, D. (2015). Why resilience is unappealing to social science: theoretical and empirical investigations of the scientific use of resilience. Sci. Adv. 1:e1400217. doi: 10. 1126/sciadv.1400217

Pelling, M., and Manuel-Navarrete, D. (2011). From resilience to transformation: the adaptive cycle in two mexican urban centers. Ecol. Soc. 16:11.

Persichillo, M. G., Bordoni, M., and Meisina, C. (2017). The role of land use changes in the distribution of shallow landslides. Sci. Total Environ. 574, 924-937. doi: 10.1016/j.scitotenv.2016.09.125

Petley, D. N., Dunning, S. A., and Rosser, N. J. (2005). "The analysis of global landslide risk through the creation of a database of worldwide landslide fatalities," in Landslide Risk Management, eds O. Hungr, R. Fell, R. Counture, and E. Ebergardt (Amsterdam: Balkema), 367-374.

Petley, D. N., Hearn, G. J., Hart, A., Rosser, N. J., Dunning, S. A., Oven, K., et al. (2007). Trends in landslide occurrence in Nepal. Nat. Hazards 43, 23-44. doi: 10.1007/s11069-006-9100-3

Petrone, A., and Perti, F. (2013). "Soil bioengineering measures in latin america: authochtonal cuttings suitability," in Landslide Science and Practice, eds C. Margottini, P. Canuti, and K. Sassa (Berlin: Springer), 325-330.

Pisano, L., Zumpano, V., Malek, Z., Rosskopf, C. M., and Parise, M. (2017). Variations in the susceptibility to landslides, as a consequence of land cover changes: a look to the past, and another towards the future. Sci. Total Environ. 60, 1147-1159. doi: 10.1016/j.scitotenv.2017.05.231

Riessman, C. (2008). Narrative Methods for the Human Sciences. Thousand Oaks: Sage Publications.

Robinson, O. C. (2014). Sampling in interview-based qualitative research: a theoretical and practical guide. Qual. Res. Psychol. 11, 25-41. doi: 10.1080/ 14780887.2013.801543

Röling, N. G., Hounkonnou, D., Offei, S. K., Tossou, R., and Van Huis, A. (2004). Linking science and farmers' innovative capacity: diagnostic studies from Ghana and Benin. NJASWagening. J. Life Sci. 52, 3-4.

Roncoli, C., Ingram, K., and Kirschen, P. (2002). Reading the rains: local knowledge and rainfall forecasting among farmers of Burkina Faso. Soc. Nat. Res. 15, 411-430.

Sapkota, P., Keenan, R. J., Paschen, J. A., and Ojha, H. R. (2016). Social production of vulnerability to climate change in the rural middle hills of Nepal. J. Rural Stud. 48, 53-64. doi: 10.1016/j.jrurstud.2016.09.007

Schuller, M. (2012). Killing With Kindness: Haiti, International Aid, and NGOs. New Brunswick: Rutgers University Press. 
Shaw, R., Noralene, U., and Baumwoll, J. (eds) (2008). Indigenous Knowledge for Disaster Risk Reduction: Good Practices And Lessons Learnt from Asia-Pacific Region. Bangkok: UNISDR.

Sidle, R. C., Gallina, J., and Gomi, T. (2017). Landscape and urban planning the continuum of chronic to episodic natural hazards: implications and strategies for community and landscape planning. Landsc. Urban Plan. 167, 189-197. doi: 10.1016/j.landurbplan.2017.05.017

Sidle, R. C., Ziegler, A. D., Negishi, J. N., Nik, A. R., Siew, P., and Turkelboom, F. (2006). Erosion processes in steep terrain-truths, myths, and uncertainties related to forest management in Southeast Asia. Ecol. Manag. 224, 199-225. doi: 10.1016/j.foreco.2005.12.019

Silvertown, J. (2009). A new dawn for citizen science. Trends Ecol. Evol. 24, 467-471. doi: 10.1016/j.tree.2009.03.017

Stokes, A., Douglas, G. B., Fourcaud, T., Giadrossich, F., Gillies, C., Hubble, T., et al. (2014). Ecological mitigation of hillslope instability: ten key issues facing researchers and practitioners. Plant Soil 377, 1-23. doi: 10.1007/s11104-0142044-6

Stone, J., Barclay, J., Simmons, P., Cole, P. D., Loughlin, S. C., Ramón, P., et al. (2014). Risk reduction through community-based monitoring: the vigías of Tungurahua, Ecuador. J. Appl. Volcanol. 3:11.

Sudmeier-Rieux, K., Jaquet, S., Basyal, G. K., Derron, M., Devkota, S., Jaboyedoff, M., et al. (2013). "A neglected disaster: landslides and livelihoods in centraleastern Nepal," in Landslide Science and Practice, eds C. Margottini, P. Canuti, and K. Sassa (Berlin: Springer).

Sudmeier-Rieux, K., Jaquet, S., Derron, M. H., Jaboyedoff, M., and Devkota, S. (2012). A case study of coping strategies and landslides in two villages of Central-Eastern Nepal. Appl. Geogr. 32, 680-690. doi: 10.1016/j.apgeog.2011. 07.005

Tobin, G. A., Whiteford, L. M., Jones, E. C., and Murphy, A. D. (2011). The role of individual well-being in risk perception and evacuation for chronic vs. acute natural hazards in Mexico. J. Appl. Geogr. 31, 700-711. doi: 10.1016/j.apgeog. 2010.12.008

Turner, N. J., and Clifton, H. (2009). It's so different today: climate change and indigenous lifeways in British Columbia. Canada. Glob. Environ. Change 19, 180-190. doi: 10.1016/j.gloenvcha.2009.01.005

Vaciago, G. (2013). "The safeland compendium of landslide risk mitigation measures," in Landslide Science and Practice, eds C. Margottini, P. Canuti, and K. Sassa (Berlin: Springer-Verlag), 683-689. doi: 10.1007/978-3-642-31319$6 \_87$
Van Den Eeckhaut, M., Moeyersons, J., Nyssen, J., Abraha, A., Poesen, J., Haile, M., et al. (2009). Spatial patterns of old, deep-seated landslides: a case-study in the northern Ethiopian highlands. Geomorphology 105, 239-252. doi: 10.1016/ j.geomorph.2008.09.027

Vlaeminck, P., Meartens, M., Laeminck, P., Maertens, M., Isabirye, M., Vanderhoydonks, F., et al. (2016). Coping with landslide risk through preventive resettlement. optimal designing strategies through choice experiments for mount elgon region, Uganda. Land Use Policy 51, 301-311. doi: 10.1016/j.landusepol.2015.11.023

Wald, D. J., Quitoriano, V., Worden, B., Hopper, M., and Dewey, J. W. (2011). USGS “Did You Feel It?” internet-based macroseismic intensity maps. Ann. Geophys. 54, 688-707.

Walker, B., Holling, C. S., Carpenter, S. R., and Kinzig, A. (2004). Resilience, adaptability and transformability in social-ecological systems. Ecol. Soc. 9:5.

Walshe, R. A., and Nunn, P. D. (2012). Integration of indigenous knowledge and disaster risk reduction: a case study from baie martelli, pentecost Island, Vanuatu. Int. J. Disaster Risk Sci. 3, 185-194. doi: 10.1007/s13753-012-0019-x

White, I., and O'Hare, P. (2014). From rhetoric to reality: which resilience, why resilience, and whose resilience in spatial planning? Environ. Plan. C Gov. Policy 32, 934-950. doi: 10.1068/c12117

Wisner, B. (2006). "Self-assessment of coping capacity: participatory, proactive and qualitative engagement of communities in their own risk management," in Measuring Vulnerability To Natural Hazards, Towards Disaster Resilient Societies, ed. J. Birkmann (Tokyo: UNU Press), 316-328.

Zook, M., Graham, M., Shelton, T., and Gorman, S. (2010). Volunteered geographic information and crowdsourcing disaster relief: a case study of the haitian earthquake. SSRN 2, 7-33.

Conflict of Interest: The authors declare that the research was conducted in the absence of any commercial or financial relationships that could be construed as a potential conflict of interest.

Copyright (c) 2019 Cieslik, Shakya, Uprety, Dewulf, Russell, Clark, Dhital and Dhakal. This is an open-access article distributed under the terms of the Creative Commons Attribution License (CC BY). The use, distribution or reproduction in other forums is permitted, provided the original author(s) and the copyright owner(s) are credited and that the original publication in this journal is cited, in accordance with accepted academic practice. No use, distribution or reproduction is permitted which does not comply with these terms. 